\title{
Rzeźby katedry wileńskiej i ich twórca Tommaso Righi*
}

$\mathrm{W}$

1777 r. z inicjatywy biskupa wileńskiego Ignacego Massalskiego rozpoczęto przebudowę katedry św. Stanisława w Wilnie. Bezpośrednim powodem tego przedsięwzięcia była konieczność odbudowy świątyni po zniszczeniach wywołanych zawaleniem się osiem lat wcześniej (w 1769 r.) wieży frontowej i spowodowane tym częściowe uszkodzenie sklepień. Pracami, które prowadzono z przerwami do roku 1801, kierował początkowo architekt Józef Sacco (według jego projektu odbudowano w latach 1777-1783 jedynie wieżę katedralna), a następnie, od początku 1783 do końca 1790 r., Wawrzyniec Gucewicz ${ }^{1}$. Gucewicz cieszył się opieką biskupa Massalskiego, który po nauce w Akademii Wileńskiej wysłał go w latach 1776-1777 na swój koszt na studia do Rzymu, a w roku 1778 zabrał w podróż po krajach północnej Europy, związaną z podjętą wówczas odbudową wileńskiej katedry. Byli m.in. w Berlinie, Poczdamie i Hamburgu, gdzie zamawiano niezbędne materiały. Stamtąd w 1780 r. (lub jeszcze w końcu 1779 r.) Gucewicz wyjechał do Paryża. Podczas półtorarocznego tam pobytu studiował architekturę, ucząc się podobno pod kierunkiem architektów Jacques-Germain'a Soufflota (zmarłego w 1780 r.) i Claude-Nicolas'a Ledoux, wybitnych przedstawicieli francuskiego klasycyzmu, oraz uczęszczając do szkoły architektonicznej prowadzonej przez JacquesFrançois'a Blondela. Do Wilna wrócił w początkach 1781 r. i dwa lata później objął kierownictwo odbudowy katedry.

Prace przy przebudowie świątyni prowadzone pod kierunkiem Gucewicza ruszyły w 1784 r. Wówczas biskup Massalski zaczął sprowadzać z zagranicy potrzebne materiały (kamień, kamienne detale architektoniczne, blachę ołowianą i miedziana), dostarczane drogą morską z Bremy i Lubeki za pośrednictwem domów handlowych w Hamburgu i Bremie; dostawy trwały do roku 1791². Najpewniej w 1784, a może jeszcze w $1783 \mathrm{r}$.

\footnotetext{
* Niniejszy tekst powstał na podstawie referatu wygłoszonego na międzynarodowej konferencjiStoleczne katedry obojga narodów. Kościoly biskupie w Krakowie $i$ Wilnie, która odbyła się 12-14 października 2016 r. w Pałacu Wielkich Książąt Litewskich w Wilnie, a została zorganizowana przez Muzeum Narodowe - Pałac Wielkich Książąt Litewskich w Wilnie oraz Zamek Królewski na Wawelu - Państwowe Zbiory Sztuki w Krakowie.

${ }^{1}$ Zob. Stanisław LORENTZ, „Wawrzyniec Gucewicz. Na marginesie monografii: E. Budreika, architekturos Kandidatas, Architektas Laurynas Stuoka Gucevicius, Vilnius 1954", Biuletyn Historii Sztuki, 20: 1958, nr 3-4, s. 367-380; id., „Gucewicz Wawrzyniec”, [w:] Polski stownik biograficzny, t. 9, Wrocław-Warszawa-Kraków 1960-1961, s. 133-135; Eduardas BUDREIKA, „Działalność architektoniczna Wawrzyńca Gucewicza. Wybrane zagadnienia”, Lituano-Slavica Posnaniensia. Studia Historiae Artium, 5: 1991 (1992), s. 171-193.

${ }^{2}$ LORENTZ, „Gucewicz Wawrzyniec...”, s. 134.
} 
Gucewicz stworzył koncepcję monumentalnej klasycystycznej budowli, wykorzystując swoje paryskie doświadczenia. Wiadomo, że w marcu 1784 r. opracował ,abrysy” wileńskiej katedry dla króla Stanisława Augusta ${ }^{3}$. W zbiorach królewskich znajdował się też wykonany przez niego projekt odbudowywanej świątyni, opatrzony napisami: „Kathedra Wilenska” i naniesionym ręką monarchy „Widok optyczny, iak ma bydź Cathedra Wilenska, w Roku 1786. wykonany"4 (il. 1). Zdaniem badaczy pierwowzorem fasady budowli mogła być kompozycja zamieszczona w albumie francuskiego architekta Marie-Josepha Peyre'a z 1765 r. ${ }^{5}$ Do wykonania dużego zespołu rzeźb mających ozdobić nową fasadę wileńskiej świątyni biskup Massalski zaangażował znanego rzymskiego rzeźbiarza Tommasa Righiego, który przyjechał z Włoch do Wilna w 1784 r.

O wykonanych przez Righiego rzeźbach znajdujemy w dawnej literaturze krótkie przeważnie wzmianki, z określeniem ich tematów i osoby autora ${ }^{6}$. W dotychczasowych badaniach nie próbowano jednak wyjaśnić, dlaczego do Wilna został sprowadzony właśnie Righi, artysta z dalekiego Rzymu będący wówczas w dość już podeszłym wieku, ani dlaczego posągi i reliefy zdobiące wileńską świątynię tak dalece odbiegają swoim charakterem od klasycystycznych form fasady, na którą zostały przeznaczone.

Inicjator i zleceniodawca przebudowy katedry, biskup wileński Ignacy Massalski (1726-1794), osoba gruntownie wykształcona i lubiąca otaczać się ludźmi nauki i sztuki, był związany z Rzymem od czasu swoich studiów ${ }^{7}$. W rzymskiej Sapienzy otrzymał

\footnotetext{
${ }^{3}$ LORENTZ, ,Wawrzyniec Gucewicz ...”, s. 373.

${ }^{4}$ Projekt przechowywany obecnie w Gabinecie Rycin Biblioteki Uniwersyteckiej w Warszawie, Inw. zb. d. 8005 (dawniej: Zbiór Królewski, P. $186 \mathrm{nr}$ 164), pióro, tusz, lawowanie w tonie szarym, pędzel, akwarela, na papierze żeberkowym. 19,2×31,2 cm, sygn. „Arch. G. del..”. O nim: Katalog rysunków z Gabinetu Rycin Biblioteki Uniwersyteckiej w Warszawie, cz. 2: Miejscowości różne. Rysunki architektoniczne, dekoracyjne, plany i widoki z XVIII i XIX wieku, oprac. Teresa SULERZYSKA, Warszawa 1969, s. 206 poz. 904; LORENTZ, Wawrzyniec Gucewicz...”, s. 373 i il. na s. 372; Stanisław LORENTZ, Andrzej ROTTERMUND, Klasycyzm w Polsce, Warszawa 1984, s. 242 poz. 31 oraz il. na s. 39 (z datowaniem na rok 1783).

${ }^{5}$ Marie-Joseph PEYRE, Oeuvres d'Architecture, Paris 1765, pl. I: Portail d'Église; por. Tadeusz Stefan JAROSZEWSKI, Architektura doby oświecenia w Polsce: nurty i odmiany, Warszawa 1971, s. 119-121 (Studia z Historii Sztuki, t. 3).

${ }^{6}$ Sebastiano CIAMPI, Notizie di medici, maestri di musica e cantori, pittori, architetti, scultori ed altri artisti italiani in Polonia e polacchi in Italia, Lucca 1830, s. 119-120; id., Bibliografia critica delle antiche reciproche corrispondenze politiche, ecclesiastiche, scientifiche, letterarie, artistiche dell'Italia colla Russia, colla Polonia..., t. 2, Firenze 1839, s. 265; Józef Ignacy KRASZEWSKI, Wilno od poczatków jego do roku 1750, t. 2, Wilno 1840, s. 197-198; Franciszek Maksymilian SOBIESZCZAŃSKI, Wiadomości historyczne o sztukach pięknych $w$ dawnej Polsce, t. 2, Warszawa 1849, s. 268-269; Jan ze Śliwina [Adam Honory KIRKOR], Przechadzki po Wilnie i jego okolicach, Wilno 1859, s. 13 15; Wacław PRZYBYLSKI, „Kościół katedralny w Wilnie”, Tygodnik Ilustrowany, 1863, nr 196, s. 253; Witold ZAHORSKI, Katedra wileńska, Wilno 1904, s. 50-51, 64; Francesco Foucault de DAUGNON, Gli italiani in Polonia dal IX secolo al XVIII. Note storiche con brevi cenni genealogici, araldici e biografici, t. 2, Crema 1906, s. 284; Jan KURCZEWSKI, Kościół zamkowy, czyli katedra wileńska..., cz. I, Wilno 1908, s. 225; Zygmunt BATOWSKI, „Righi Tommaso", [w:] Ulrich THIEME, Felix BECKER, Allgemeines Lexikon der Bildenden Künstler von der Antike bis zur Gegenwart, t. 28, Leipzig 1934, s. 354; Bazylika wileńska, Wilno [b.r.], s. 17-18, 21; Juliusz KŁOS, Wilno, przewodnik krajoznawczy, Wilno 1937, s. 117-119; Piotr ŚLEDZIEWSKI, „Dialog albo rozmowa o adoracji Krzyża Św. na fasadzie bazyliki wileńskiej”, Środy Literackie (Wilno), 1937, nr 7, s. 1-19. Ostatnio o rzeźbach: Katarzyna MIKOCKA-RACHUBOWA, „Włoscy rzeźbiarze na dworze króla Stanisława Augusta”, Rocznik Historii Sztuki, 29: 2004, s. 110; ead., „Righi Tommaso", [w:] Slownik artystów polskich i obcych w Polsce dziatajacych (zmartych przed 1966 r.). Malarze, rzeźbiarze, graficy, t. 8, Warszawa 2007, s. 365; ead., ,Rome and sculpture in Poland in the Reign of King Stanislaus Augustus (1764-1795)", [w:] Poland and Artistic Culture of Western Europe 14th-20th Century, eds. Barbara PRZYBYSZEWSKA-JARMIŃSKA, Lech SOKÓŁ, Frankfurt am Main 2014, s. 289 i il. 8; ead., Rzeźba wtoska w Polsce okoto 1770-1830, Warszawa 2016, t. 1, s. 23, t. 2, s. 491-499.

${ }^{7}$ Zob. Irena SZYBIAK, „Massalski Ignacy”, [w:] Polski stownik biograficzny, t. 20, Wrocław-Warszawa-KrakówGdańsk 1975, s. 135-139.
} 


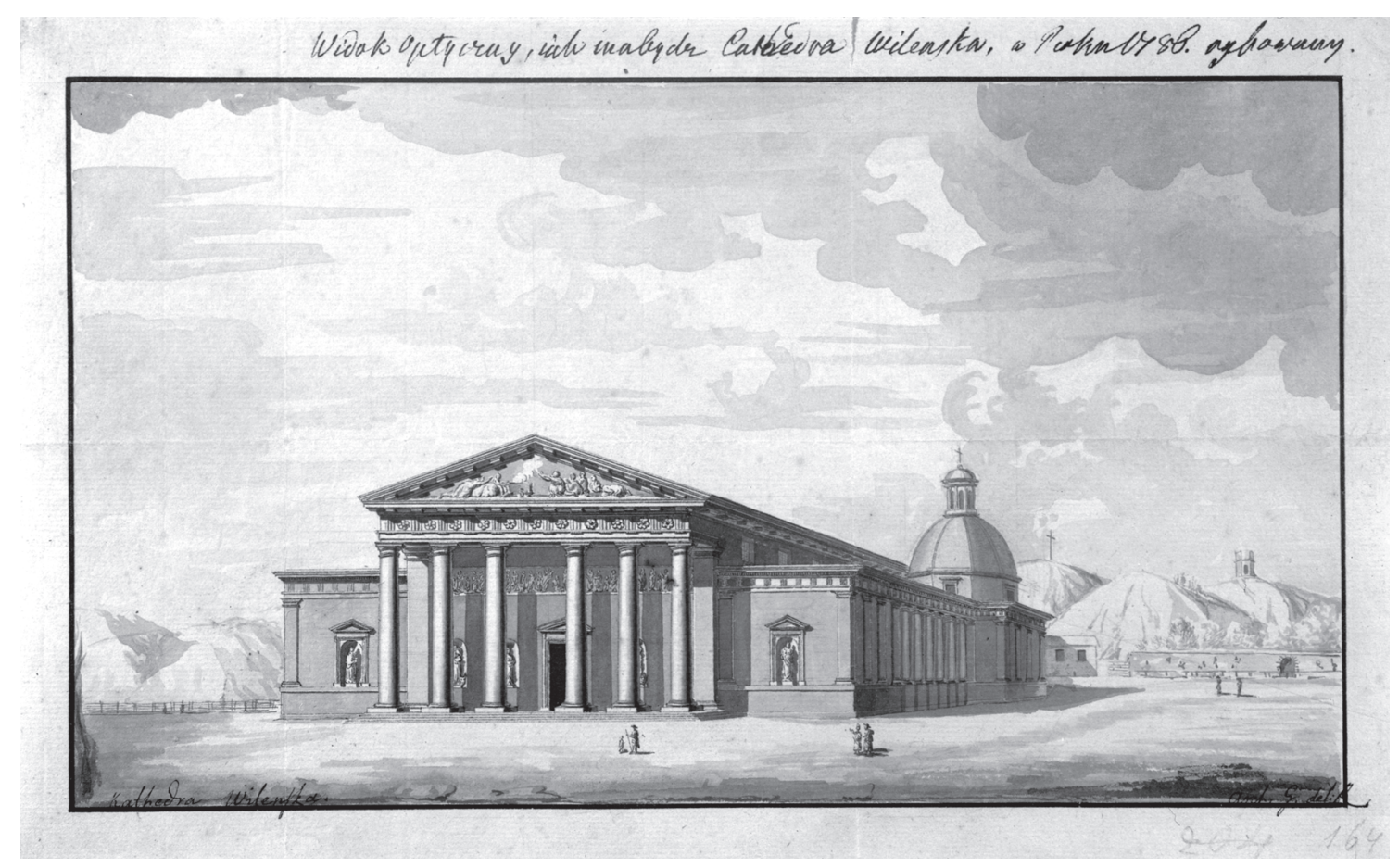

1. Wawrzyniec Gucewicz, projekt katedry w Wilnie, 1786. Gabinet Rycin Biblioteki

Uniwersyteckiej w Warszawie, Inw. zb. d. 8005. Fot. Instytut Sztuki PAN w Warszawie

w 1752 r. tytuł doktora obojga praw, a w latach późniejszych kilkakrotnie przebywał w Wiecznym Mieście, utrzymywał kontakty z tamtejszymi artystami i nabywał liczne dzieła sztuki. W szczególnych relacjach pozostawał z rzeźbiarzem Vincenzem Pacettim (1746-1820), ważną postacią w rzymskim środowisku artystycznym 2. połowy XVIII w. Pacetti oprócz własnej twórczości zajmował się na dużą skalę restaurowaniem rzeźb antycznych, wykonywaniem ich kopii oraz handlem dziełami sztuki, co przyniosło mu spory majątek i sławę. Jego klientami byli podróżnicy, kolekcjonerzy i miłośnicy sztuki z całej Europy, a dostawcami najgłośniejsze osobistości spośród prowadzących wykopaliska oraz właściciele wielkich kolekcji w Rzymie i okolicach ${ }^{8}$. Od początku lat 70. XVIII w. niemal do końca życia (do 1819 r.) Pacetti prowadził diariusz, w którym szczegółowo odnotowywał wszelkie wydarzenia dotyczące własnej działalności, a także informacje o osobach odwiedzających jego pracownię i o dokonywanych w jego studiu zakupach dzieł sztuki ${ }^{9}$. W dzienniku tym wymieniany jest wielokrotnie biskup Ignacy Massalski, który zakupił w Rzymie za pośrednictwem Pacettiego liczne rzeźby. We wrześniu 1782 r. Pacetti wysłał

\footnotetext{
${ }^{8}$ Zob. MIKOCKA-RACHUBOWA, Rzeźba włoska w Polsce ..., t. 2, s. 407-422, tam wcześniejsza literatura.

${ }^{9}$ Diariusz zachowany jest w dwóch częściach: pierwsza, z lat 1773-1803, jest przechowywana w Biblioteca Universitaria Alessandrina w Rzymie (ms 321: Giornale di Vincenzo Pacetti riguardante li principali affari, e negozj del suo studio di scultura, ed altri suoi interressi particolari, incominciato dall'anno 1773 fino all'anno 1803), a druga, z lat 1803-1819, w Museo Centrale del Risorgimento w Rzymie (busta 654, fasc. 5: Giornale delle cose più importanti di pertinenza di Vincenzo Pacetti fin ora scritto in fogli volanti: ma da quest'epoca in poi, tutti si riportano per alfabeto a seconda delle loro casate, o sieno cognomi rispettivi questo di 15. Maggio 1803, 1803-1819). Obie części dziennika w kontekście kontaktów Pacettiego z Polakami zostały wykorzystane w: Katarzyna MIKOCKA-RACHUBOWA, „Rzeźbiarz rzymski Vincenzo Pacetti i Polacy”, Biuletyn Historii Sztuki, 65: 2003, nr 2, s. 261-276; ead., „O ‘Giornale’ Vincenza Pacettiego raz jeszcze”, Biuletyn Historii Sztuki, 68: 2006, nr 1, s. 103-105. Dziennik Pacettiego został ostatnio opublikowany: Roma 1771-1819. I 'Giornali' di Vincenzo Pacetti, red. Angela CIPRIANI, Giulia FUSCONI, Carlo GASPARRI, Maria Grazia PICOZZI, Lucia PIRZIO BIROLI STEFANELLI, Pozzuoli 2011 [cyt. dalej: Giornali di Pacetti...].
} 


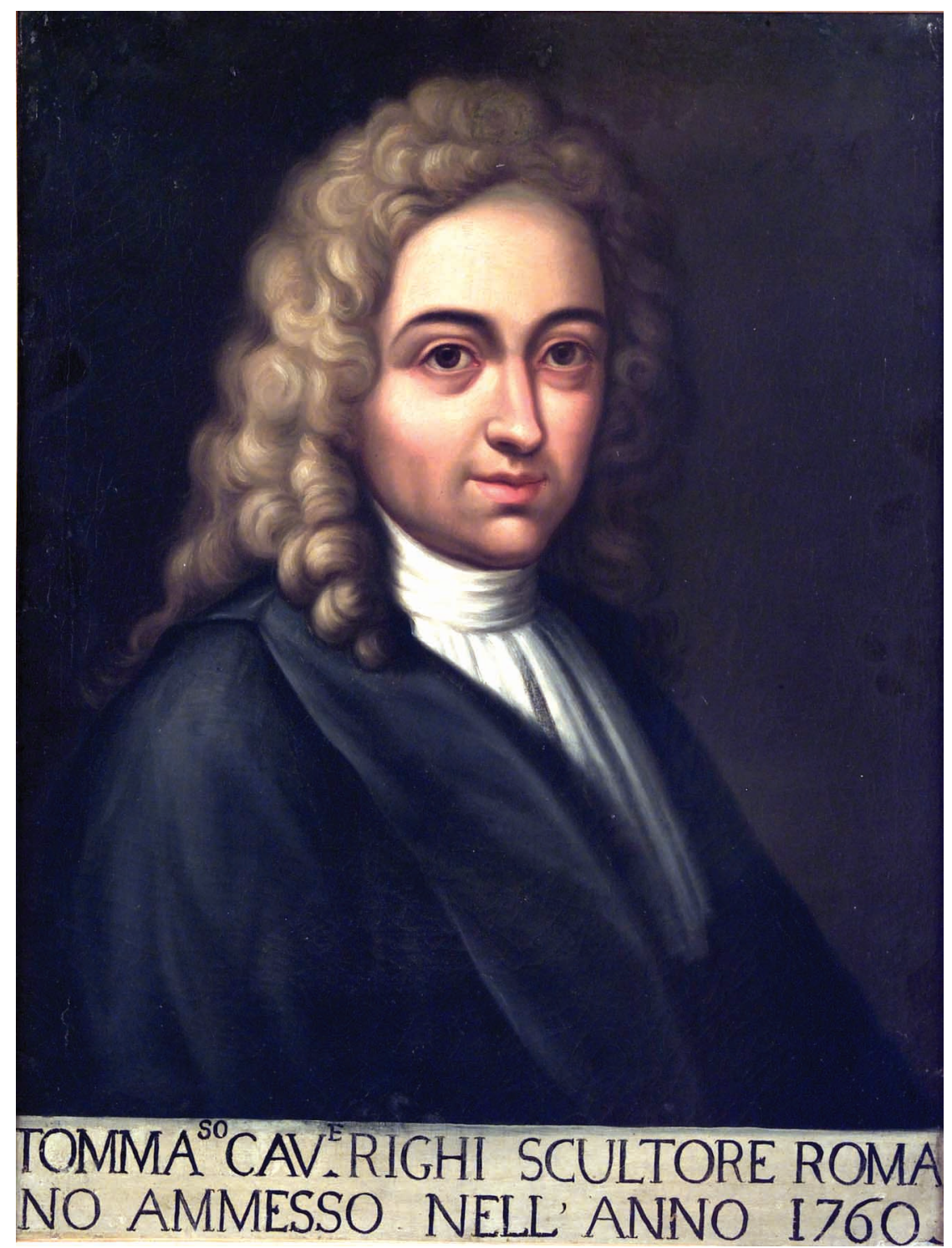

2. Francesco Pulini, Tommaso Righi, olej, płótno, $50 \times 66 \mathrm{~cm}, 1802$. Rzym, Accademia Nazionale di San Luca, inv. 0565.

Fot. www.accademiasanluca.eu

mu do Wilna sześć skrzyń, zapewne z dziełami sztuki ${ }^{10}$. W styczniu 1784 r. wspominał o rzeźbach nabytych dla biskupa wileńskiego, w marcu pisał do Wilna w sprawie zamówienia kolejnych posagów, a w czerwcu Massalski prosił go o przysłanie wykazu rzeźb „si antiche e moderne”, które planował zakupić ${ }^{11}$. W diariuszu są też wzmianki o antycznej statui, którą Pacetti zamierzał mu wówczas zaoferować ${ }^{12}$, i o dwóch puttach sprzeda-

${ }^{10}$ Giornali di Pacetti..., s. 17: Adi 19. [7bre 1782]. o consegniato al Signor de Gregori le sei casse per spedirsi al Vescovo di Vilna, Monsignor Massalski, in Polonia.

${ }^{11}$ Ibid., s. 32: Adi 30. [Gennaro 1784]. Hò riceuto lettera dal Abate Don Cornelio ove mi dice delle sculture vendute da me al Vescovo di Vilna, che nè contento, e che ne prenderà dell'altre, per la sua villa; s. 33: Adi 20. [Marzo 1784]. Hò scritto al Signor Don Cornelio in Vilna per la commissione delle statue; s. 36: Adi 7. [Giugno 1784] Hà scritto il Signor Abate Cornelio di mandargli una nota di statue si antiche, e moderne per il Vescovo di Vilna, e di varie condizione; Adi 9. [Giugno 1784] Hò presa una nota di statue dal Signor Carlo Albacini per spedire in Polonia, al Vescovo di Vilna. 12 Ibid., s. 36: Adi 10. [Giugno 1784]. Sono stato dal Signor Volpini per vedere li suoi lavori, in tal occasione hò veduto una statua antica che darò in nota per il Vescovo di Vilna, l'ultimo prezzo scudi 200. 
nych biskupowi, których rysunki miał latem 1785 r. przysłać z Wilna Franciszek Smuglewicz ${ }^{13}$.

Biskup Massalski udał się w końcu 1789 r. w zagraniczną podróż, odwiedzając m.in. Włochy i bawiąc przez pewien czas w Rzymie ${ }^{14}$. W diariuszu Pacettiego znajdują się wzmianki dotyczące owego rzymskiego pobytu, trwającego od lutego do początków września 1790 r. Artysta kilkakrotnie odwiedzał wówczas biskupa, a sam Massalski bywał w jego pracowni i oglądał znajdujące się tam rzeźby, zarówno dzieła samego Pacettiego, jak zakupione przezeń rzeźby antyczne, odrestaurowane i przeznaczone do dalszej sprzedaży, wyrażając zamiar nabycia niektórych z nich ${ }^{15}$. Pacetti zanotował też, że w maju biskup wileński zamówił swój portret u malarza Antona von Maron, przeznaczony do oddania go w mozaice i umieszczenia w Bazylice św. Piotra ${ }^{16}$.

Vincenzo Pacetti w początkach lat 60 . XVIII w. był uczniem Tommasa Righiego, który, jak Pacetti zapisał w swoim diariuszu, „,kochał go jak syna” i żegnał z wielkim żalem, gdy ten w roku 1766 opuszczał jego studio ${ }^{17}$. W późniejszych latach Pacetti utrzymywał bliskie stosunki ze swoim nauczycielem, a także z nim współpracował, np. przy dekoracji wnętrz casina Villa Borghese w końcu lat 70. XVIII w. W diariuszu Pacettiego znajdujemy wzmianki o Righim z czasu, gdy ten mieszkał w Rzymie, a także z okresu już po opuszczeniu przezeń Wiecznego Miasta ${ }^{18}$. Wydaje się zatem bardzo prawdopodobne, że to właśnie Pacetti mógł mieć bezpośredni wpływ na zatrudnienie przez biskupa Massalskiego jego dawnego nauczyciela. Righi mógł zresztą wcześniej poznać zarówno Gucewicza (na przykład w czasie jego rzymskich studiów), jak i samego biskupa Massalskiego.

Tommaso Righi, urodzony w Rzymie w 1722 lub 1723 r., uczeń znanego rzeźbiarza Filippa Della Valle, był ważną osobistością w środowisku artystycznym Wiecznego Miasta 2. połowy XVIII w. ${ }^{19}$ (il. 2). Wykonywał pomniki nagrobne do rzymskich kościołów oraz rzeźbiarskie dekoracje rzymskich świątyń i pałaców, przeważnie według projektów innych twórców, choć znane są również prace, których projekt i wykonanie były jego dziełem. Samodzielną działalność rozpoczął w końcu lat 40. XVIII w. Pierwszą znaną praca artysty był datowany na 1748 r. terakotowy model reliefu ze sceną Narodzin Marii przeznaczonego do Cappella del Voto w katedrze w Sienie, sygnowany „To.so RIGHI”. Innym wczesnym dziełem są niektóre partie dekoracji nagrobka Scipione Publicola Santacroce w kościele Santa Maria in Publicolis w Rzymie, realizowanego od 1749 r. Z roku 1754 pochodzi stiukowa dekoracja wnętrza kościoła opactwa w Grottaferrata, a w 1756 r. powstało stiukowe obramienie edicola mariana (edicola di fede) na narożniku wieży

\footnotetext{
${ }^{13}$ Ibid., s. 50: Adi 21 [Giugno 1785] Ricordarsi di scrivere in Vilna a Smuglevix, di mandarmi due disegni del putto venduto al Vescovo di Vilna che la testa è Roscio putto o sia bambina cosa assai rara.

${ }^{14}$ SZYBIAK, op. cit., s. 137.

${ }^{15}$ Giornali di Pacetti ..., s. 100 (18 lutego), s. 101 (1 marca), s. 102 (21, 22 i 25 kwietnia), s. 103 (24, 25 i 30 maja), s. 104 (20 czerwca), s. 105 (1 i 10 sierpnia), s. 106 (29 sierpnia).

${ }^{16}$ Ibid., s. 103: Adi 24. [Maggio 1790] Sono stato dal Vescovo di Vilna con il quale ancora non si può concludere niente rapporto la mia professione, mà vole il suo ritratto da Maron; Adi 25. [Maggio 1790] Hò condotto M.r Maron dal sudetto Vescovo di Vilna e presto s'incomincierà il ritratto dipinto per farlo mettere in mosaico a San Pietro; Adi 30. [Maggio 1790] Sono stato dal Vescovo di Vilna per l'Affare di M.r Maron.

${ }^{17}$ Ibid., s. 303: Adi 28. Aprile 1813. In questo studio oggi venni la prima volta circa 46. anni sono per giovane del fu Pietro Pacilli Scultore, essendo uscito dallo studio di Tommaso Righi con grandissimo suo dispiacere per che veramente mi amava come un figlio, ma tutto ciò dovetti fare per commando de miei superiori per le grandi angustie.

${ }^{18}$ Ibid., s. 37, 47, 94, 101, 223, 229.

${ }^{19}$ Zob. MIKOCKA-RACHUBOWA, „Righi Tommaso...”, s. 359-371 (tu pełny wykaz źródeł archiwalnych i kompletna bibliografia); ead., Rzeźba włoska w Polsce ..., t. 2, s. 484-506 i według indeksu.
} 


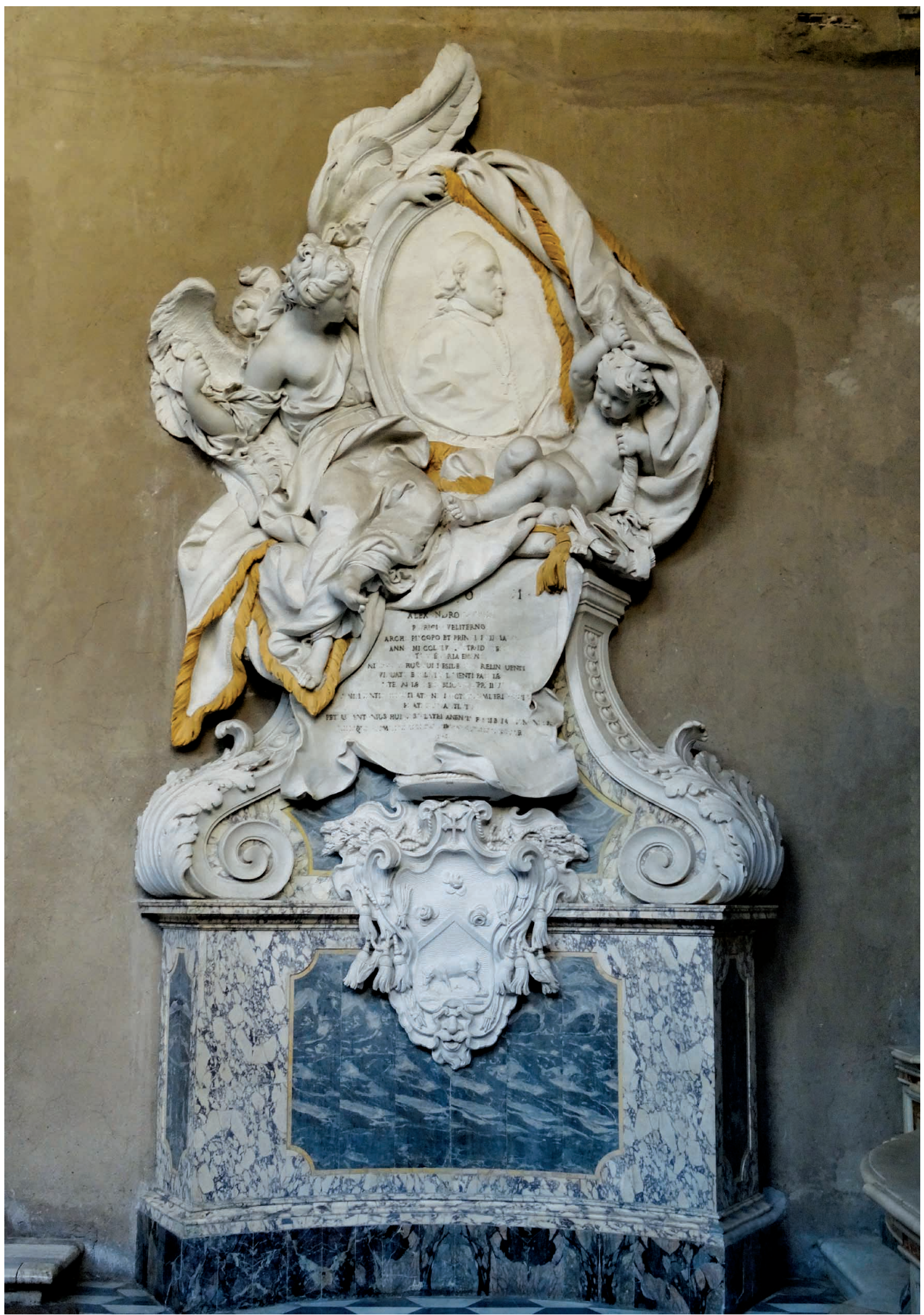

3. Tommaso Righi, pomnik nagrobny arcybiskupa Alessandra Borgii, marmur biaty, braz złocony, 1767. Rzym, Baptysterium przy bazylice San Giovanni in Laterano, kaplica Sante Seconda e Ruffina. Fot. Katarzyna Mikocka-Rachubowa 


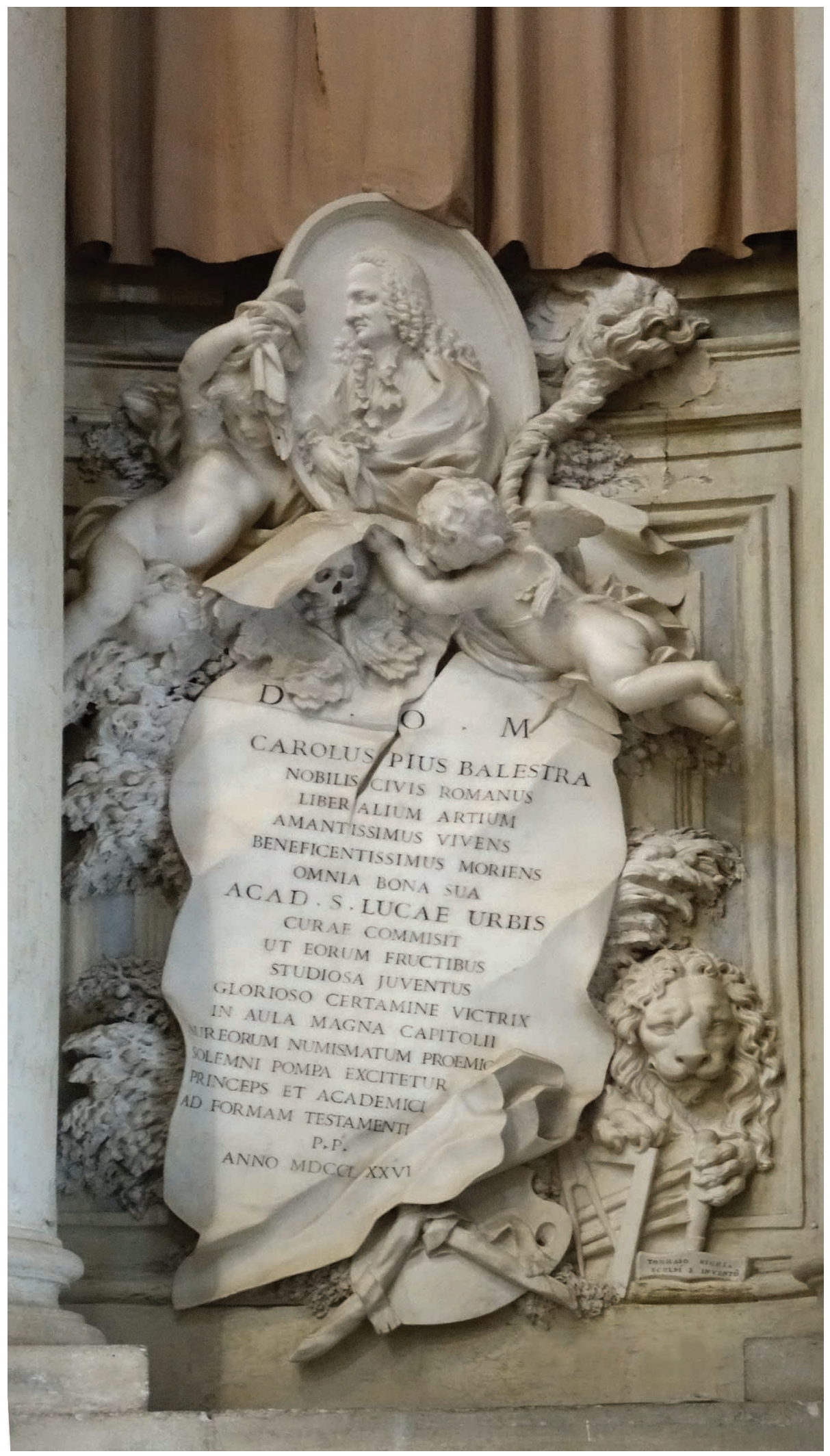

4. Tommaso Righi, pomnik nagrobny Carla Pio Balestry, marmur biaty, 1776. Rzym, kościót Santi Luca e Martina. Fot. Katarzyna Mikocka-Rachubowa 
zegarowej oratorium Filipinów przy Chiesa Nuova w Rzymie. W latach 60. XVIII w. Righi wykonał kilka pomników nagrobnych. W kaplicy Sante Seconda e Ruffina w Baptysterium przy rzymskiej bazylice San Giovanni in Laterano stoją pomniki arcybiskupa Niccolò Lercariego (z 1760 r.) i kardynała Niccolò Marii Lercariego (z 1761 r.), gdzie był on autorem przedstawień zmarłych, oraz pomnik arcybiskupa Alessandra Borgii ustawiony wiosną 1767 r., będący samodzielnym dziełem artysty, o czym świadczy sygnatura „THOMAS RIGHI INVENIT ET SCULPSIT” (il. 3). W 1764 r. stworzył nagrobek księżny Teresy Grillo Pamphili, sygnowany „TOMMASO RIGHI ROMANO FECIT”, do kościoła Santa Maria degli Angeli w Asyżu, a w 1768 r. nagrobek rzymskiego senatora Szweda Nicola Bielke (według projektu Pietra Camporese) stojący w kościele Santa Brigida przy Piazza Farnese. W latach 1774-1776 powstał pomnik kardynała Camilla Merlini Paolucciego umieszczony w rzymskim kościele San Marcello in Corso, wykonywany przez Righiego „senza veruna direzione”, a z roku 1776 pochodzi nagrobek Carla Pio Balestry, sygnowany „TOMMASO RIGHI SCULPÌ E INVENTÒ”, ustawiony w kościele Santi Luca e Martina (il. 4). Balestra, zmarły w 1763 r. architekt, inżynier i malarz, był fundatorem nagrody przyznawanej jako Premio Balestra przez Akademię Św. Łukasza, która ogłosiła konkurs na realizację jego nagrobka. Righi przedstawił w 1770 r. kilka projektów i model w glinie, który został wybrany. Ponieważ jednak jego realizacja byłaby zbyt kosztowna, jesienią 1772 r. dokonano kolejnej selekcji spośród zaprezentowanych wówczas przez artystę modeli. Przedstawione przez Righiego barokizujące (barocchetto) bozzetto do tego pomnika wywołało gwałtowną dysputę między przychylnie oceniającymi go akademikami a Giovannim Battistą Piranesim, który w liście do Antona Raphaela Mengsa proponował przeprowadzenie radykalnych zmian w projekcie, domagając się dzieła utrzymanego w duchu bardziej klasycznym. Spór wygrał Righi, marnując przy tym okazję do dokonania zmian w swojej, już wówczas zapóźnionej stylistycznie i raczej konserwatywnej, sztuce. Z tego czasu pochodzi także stiukowa dekoracja wnętrza kościoła San Romualdo w opactwie kamedułów we Frascati, powstała najpewniej niedługo przed konsekracją świątyni w 1776 r., rozmieszczona w absydzie, na ścianach kaplic bocznych i na ścianach nawy.

Przykład współpracy Righiego z wybitnymi indywidualnościami artystycznymi środowiska rzymskiego tego czasu znajdujemy w kościele Santa Maria del Priorato na Awentynie, wzniesionym w latach 1764-1765 dla Zakonu Kawalerów Maltańskich przez Giovanniego Battistę Piranesiego, gdzie według projektu tego architekta artysta wykonał rzeźbiarską dekorację w stiuku, m.in. ołtarza głównego. Righi uczestniczył w tak renomowanych ówczesnych przedsięwzięciach, jak dekoracja Złotego Salonu (Salone d'Oro) w Palazzo Chigi na Montecitorio w Rzymie w latach 1765-1767 - jego dziełem jest tam bogata dekoracja figuralna salonu, zrealizowana w dużej części według własnych projektów - czy też dekoracja wnętrz casina Villa Borghese, gdzie przy pracach prowadzonych na zlecenie Marcantonia Borghese zatrudniona była grupa najwybitniejszych rzymskich rzeźbiarzy, a Righi w latach 1777-1779 wykonał tam rzeźbiarską dekorację kilku sal.

Tommaso Righi należał do najważniejszych rzymskich stowarzyszeń i uczelni artystycznych: od 1757 r. do Congregazione dei Virtuosi al Pantheon (w 1779 r. został jej regentem), a od roku 1760 do Akademii Św. Łukasza, gdzie sprawował wiele funkcji i był profesorem, był też wielokrotnym dyrektorem prowadzonej przez tę akademię Scuola Libera del Nudo na Kapitolu. Kariera artysty przez długie lata rozwijała się pomyślnie, a jego działalność spotykała się z dużym uznaniem - był niewątpliwie jednym z najbardziej interesujących i pomysłowych reprezentantów rzeźby późnego baroku w Wiecznym Mie- 


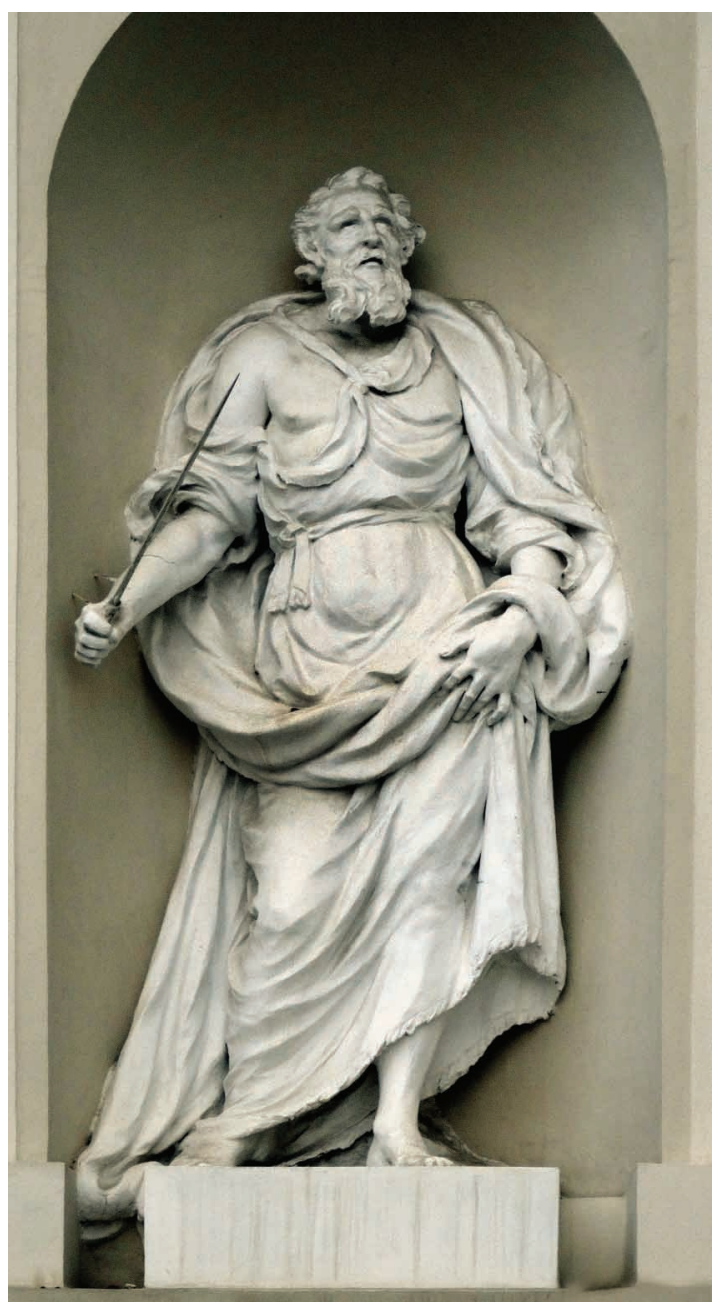

5. Tommaso Righi, Abraham, stiuk w technice narzutu, między 1786 a 1790. Wilno, katedra św. Stanistawa.

Fot. Katarzyna Mikocka-Rachubowa

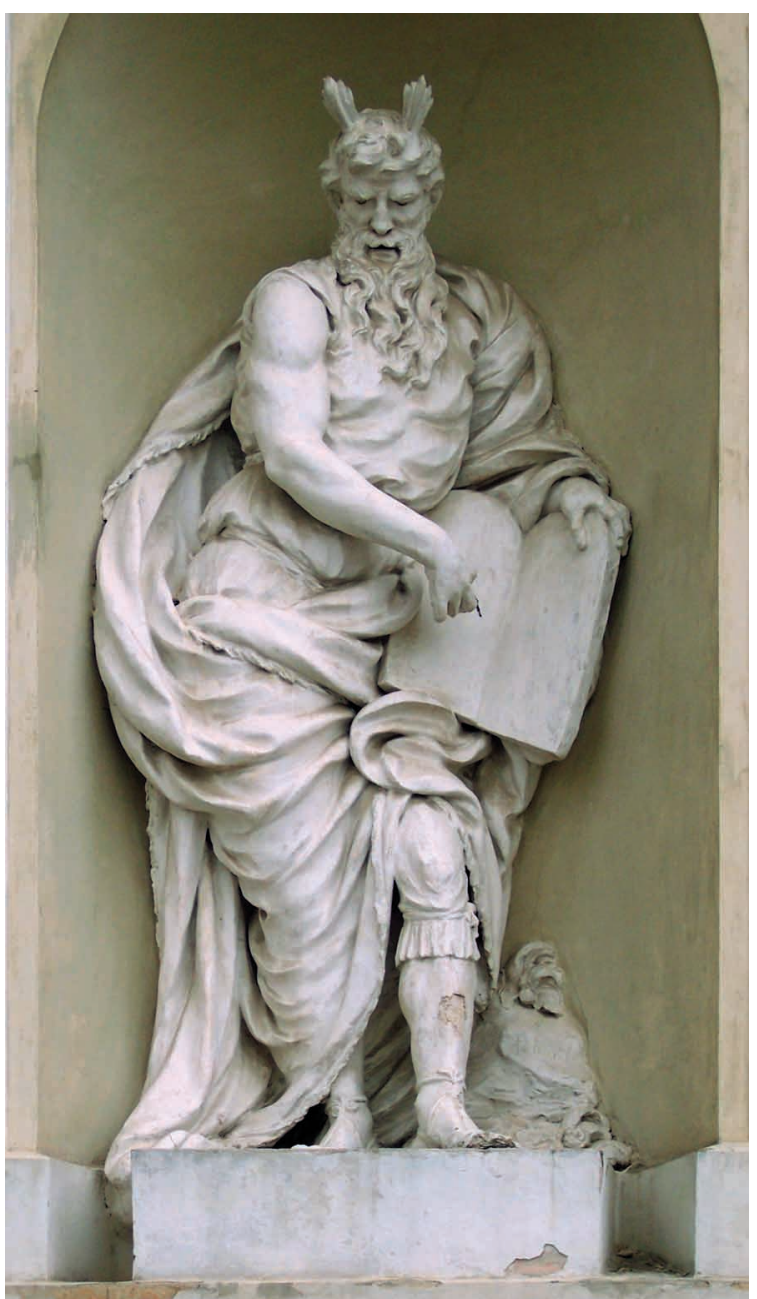

6. Tommaso Righi, Mojżesz, stiuk w technice narzutu, między 1786 a 1790. Wilno, katedra św. Stanistawa.

Fot. Katarzyna Mikocka-Rachubowa

ście. Najwybitniejszy rzeźbiarz okresu neoklasycyzmu, Antonio Canova, wspominając po latach swój młodzieńczy pobyt w Rzymie w 1780 r., spośród rzeszy pracujących tam wówczas włoskich rzeźbiarzy zapamiętał jedynie pięciu - wśród nich Tommasa Righiego, o którym pisał: „Tommaso Righi. Stimato dal volgo per la sua moderna e manierata fantasia" ${ }^{20}$.

Nasuwa się pytanie, dlaczego Righi, artysta cieszący się przez całe życie sporym uznaniem w rzymskim środowisku, zdecydował się na wyjazd z rodzinnego miasta do dalekiego Wilna. Można przypuszczać, że bezpośrednim powodem takiej decyzji był postępujący w końcu ósmego dziesięciolecia XVIII w. ewidentny schyłek jego artystycznej działalności. Związane $\mathrm{z}$ brakiem zamówień trudności finansowe wpływały na kondycję ekonomicznąjego i rodziny, a do osobistych perturbacji dołączyła się ogólna sytuacja, w jakiej znalazła się produkcja artystyczna w Rzymie końca lat 70. XVIII w. Nastąpił wówczas

\footnotetext{
${ }^{20}$ List Canovy do Leopolda Cicognary z Rzymu 29 marca 1817 r.; cyt. za: Edizione nazionale delle opere di Antonio Canova, t. 18: Antonio CANOVA, Epistolario (1816-1817), a cura di Hugh HONOUR, Paolo MARIUZ, t. 2, Roma 2003, s. 748.
} 


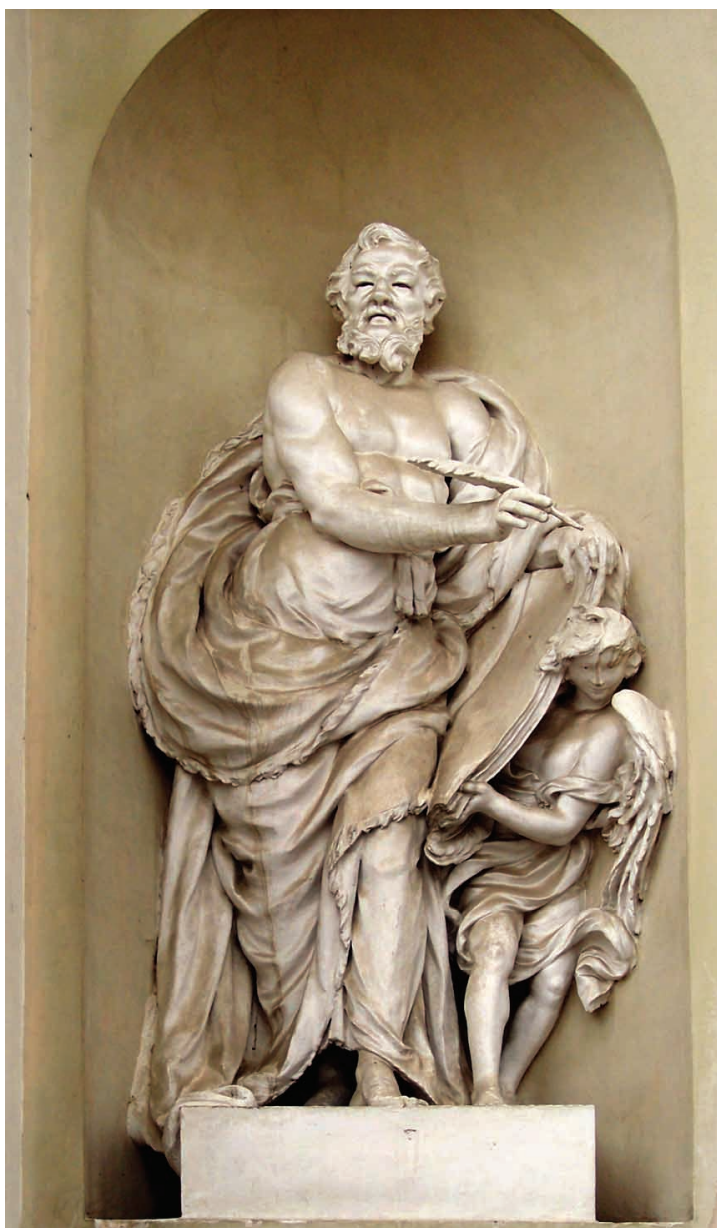

7. Tommaso Righi, Św. Mateusz, stiuk w technice narzutu, między 1786 a 1790. Wilno, katedra św. Stanistawa.

Fot. Katarzyna Mikocka-Rachubowa

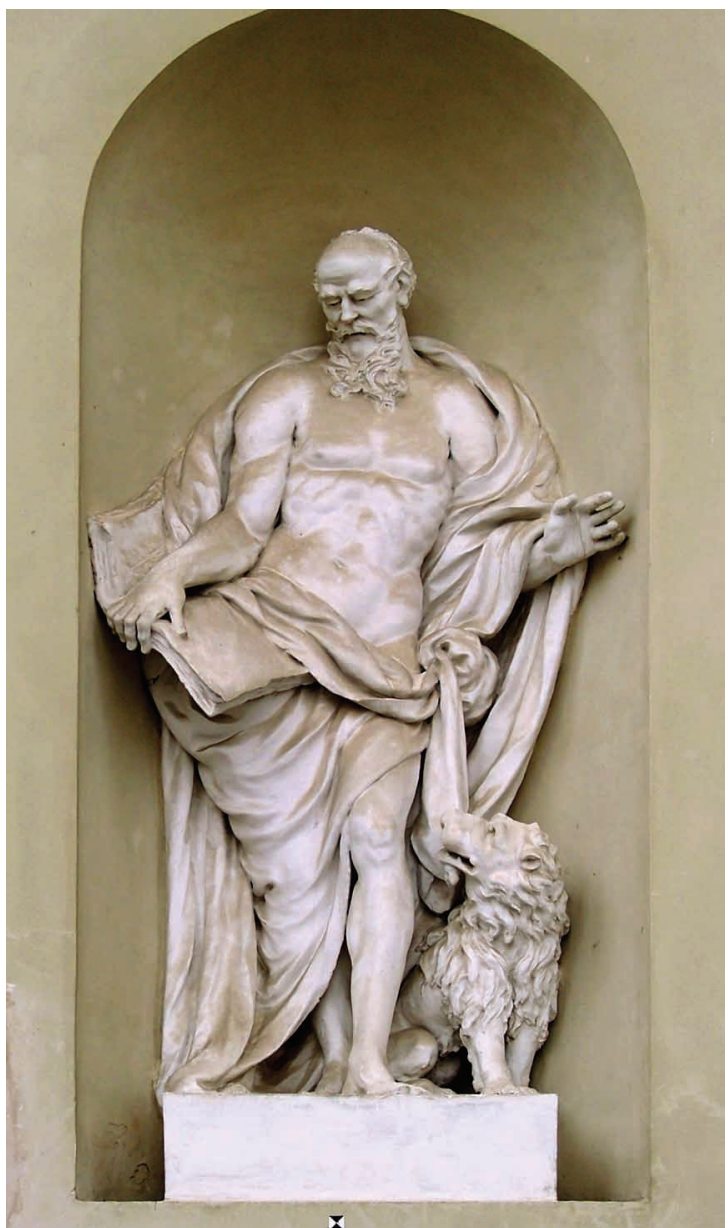

8. Tommaso Righi, Św. Marek, stiuk w technice narzutu, między 1786 a 1790. Wilno, katedra św. Stanistawa.

Fot. Katarzyna Mikocka-Rachubowa

znaczny spadek liczby wielkich zamówień, a dla rzeźbiarzy głównym polem działalności stała się restauracja antycznych marmurów, dostarczanych przez prowadzone stale wykopaliska, oraz wykonywanie ich kopii, a także rozwijający się na dużą skalę handel zarówno starożytnymi rzeźbami, jak ich substytutami, jakimi stawały się współczesne kopie i dzieła wzorowane na antyku, nabywane masowo przez międzynarodowe towarzystwo odwiedzające Wieczne Miasto. Righi w swojej twórczości nigdy nie był szczególnie zainteresowany antykiem. Znana jest jedna tylko wzmianka o restaurowaniu przez niego antycznej rzeźby - statui Euterpe przewożonej wiosną 1784 r. do Museo Pio Clementino ${ }^{21}$. Mógł oczywiście okazjonalnie zajmować się konserwacją antyków, choć źródła o tym nie wspominają. Z pewnością jednak nie umiał skorzystać z możliwości, jakie dawała powszechna wówczas praktyka restaurowania, kopiowania i imitacji dzieł starożytnych mistrzów, przynosząca rzymskim rzeźbiarzom znaczną renomę i duże zyski. Nic więc dziwnego, że wraz z coraz rzadszym otrzymywaniem zamówień w Rzymie artysta próbował kontynuować działalność w którymś $\mathrm{z}$ ośrodków oddalonych od rodzinnego

\footnotetext{
${ }^{21}$ Diario Ordinario [di Roma del Chracas], 1784, nr 970 (z 17 kwietnia), s. 4: La statua maggiore del naturale rappresentante Euterpe ritrovata alla antica Otricoli ben supplita dal Sig. Tommaso Righi.
} 


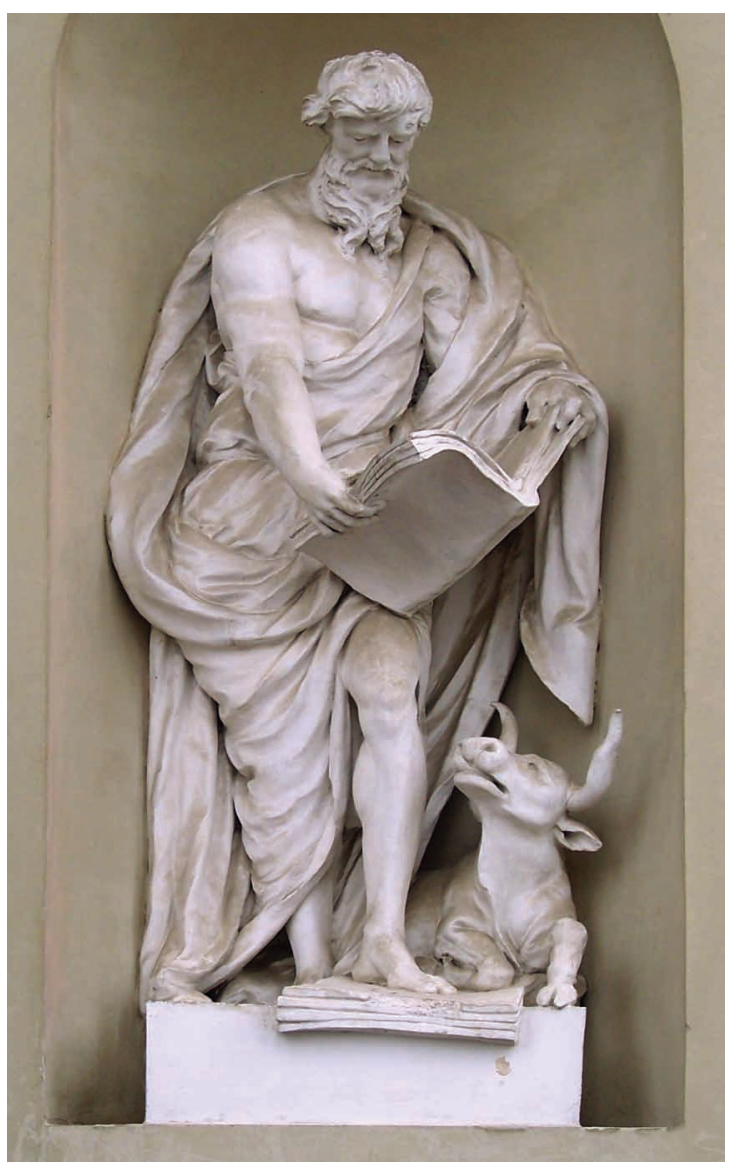

9. Tommaso Righi, Św. Łukasz, stiuk w technice narzutu, między 1786 a 1790.

Wilno, katedra św. Stanisława.

Fot. Katarzyna Mikocka-Rachubowa

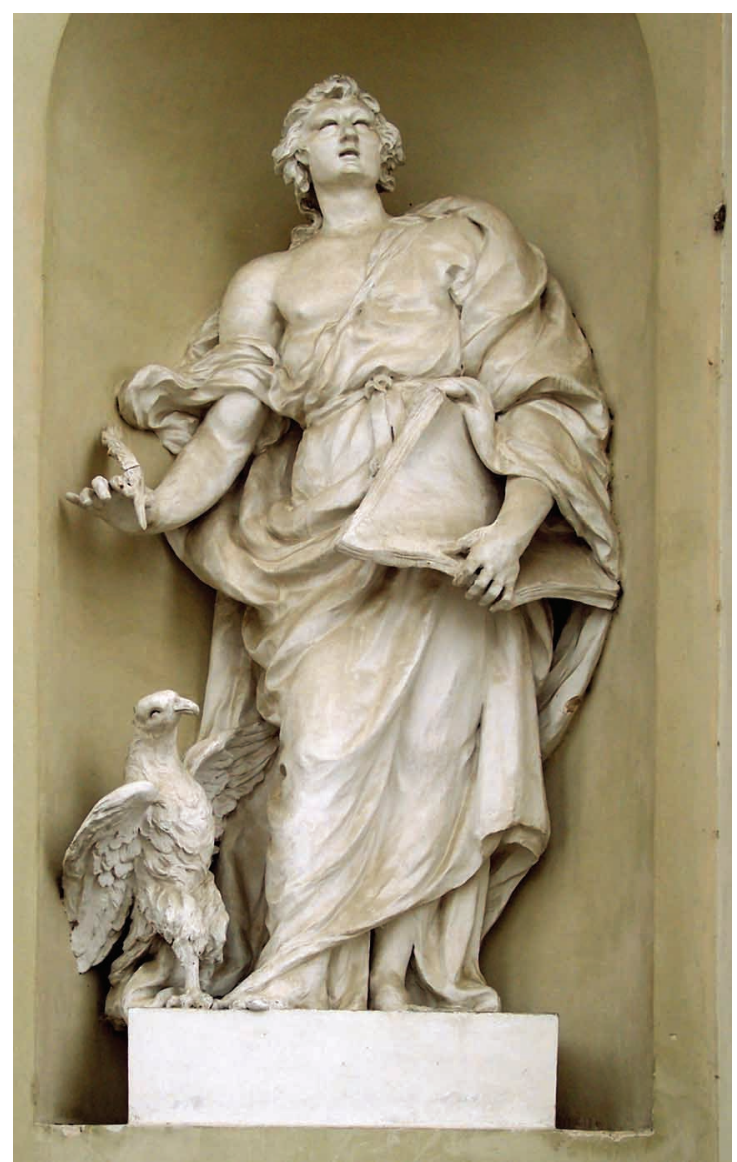

10. Tommaso Righi, Św. Jan, stiuk w technice narzutu, między 1786 a 1790.

Wilno, katedra św. Stanisława.

Fot. Katarzyna Mikocka-Rachubowa

miasta, gdzie nadal aktualne były tendencje zgodne z jego późnobarokowym repertuarem i gdzie nie było konieczności ciagłej konfrontacji z antykiem ani zależności od generujących ją teorii. Po wykonaniu w początkach lat 80 . kilku prac o niewielkim znaczeniu Righi ostatecznie zdecydował się opuścić Rzym, a najpewniej zimą 1783/1784 r. skonkretyzowało się zaproszenie biskupa Massalskiego, który zaangażował go jako swojego nadwornego rzeźbiarza do Wilna.

Righi wyjechał z Rzymu do Polski dokładnie 17 maja 1784 r. (datę tę odnotował w swoim diariuszu Vincenzo Pacetti) ${ }^{22}$. Był już w podeszłym jak na owe czasy wieku, skończył bowiem 60 lat. Na kilka miesięcy przed podróżą wyprzedawał majątek, również narzędzia służące mu do pracy (np. w marcu 1784 r. Antonio Canova nabył od niego cyrkle) ${ }^{23}$. W drodze do Wilna ów „celebre scultore romano” zatrzymał się w Warszawie, zaopatrzony w Rzymie w list z rekomendacją i prośbą o opiekę adresowany do nuncjusza papieskiego Gaetana Ghigiottiego ${ }^{24}$. Być może z ówczesnym pobytem Righiego w Warszawie wiązało się

\footnotetext{
${ }^{22}$ Giornali di Pacetti..., s. 37: Adi 18. [Maggio 1784] Ieri parti da Roma il Signor Tommaso Righi.

${ }^{23}$ Edizione nazionale delle opere di Antonio Canova, t. 1: Scritti, a cura di Hugh HONOUR, Roma 1994, s. 196.

${ }^{24}$ Archiwum Główne Akt Dawnych w Warszawie, Archiwum Gaetana Ghigiottiego, nr 606, k. 6-6v (list Francesca Romanellego z Rzymu 13 maja 1784 r.). Do poznanego wówczas nuncjusza Righi wysyłał później z Wilna, w 1788 r., listy z prośbami o protekcję dla swojego mieszkającego w Rzymie syna Antonia, który chciał zostać zatrudniony przy Kamerze Apostolskiej; ibid., nr 638, k. 1-2, 3, 4-4v.
} 


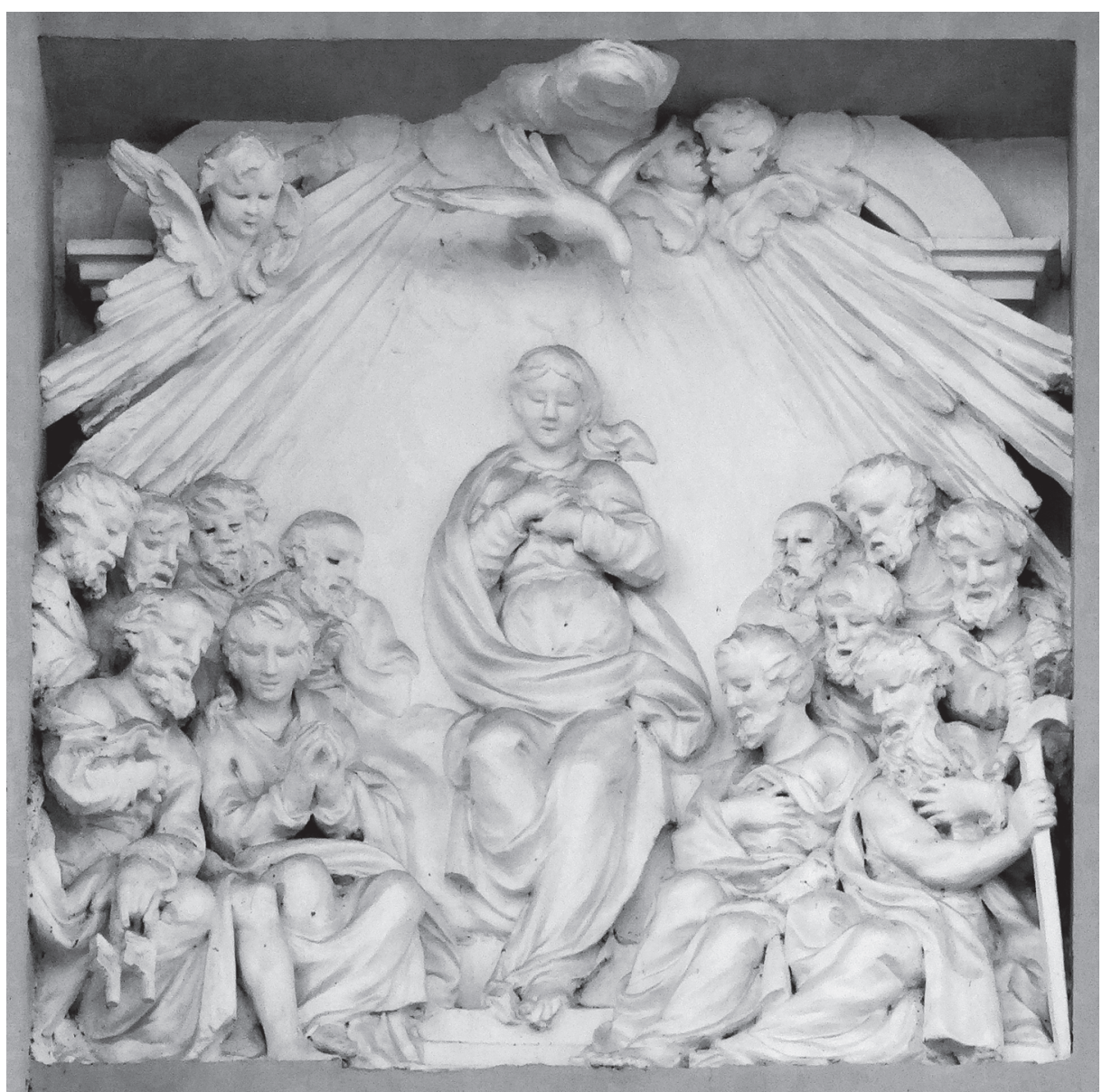

11. Tommaso Righi, Zesłanie Ducha Świętego, stiuk w technice narzutu, między 1786 a 1790. Wilno, katedra św. Stanisława.

Fot. Katarzyna Mikocka-Rachubowa

wpisanie w sierpniu 1785 r. króla Stanisława Augusta w poczet członków honorowych Akademii Św. Łukasza, co nastąpiło, jak zaznaczono, , agli stimoli del suo individuo Tommaso Righi"25.

Righi był zatrudniony w Wilnie przez biskupa Massalskiego przez okres sześciu lat i czterech miesięcy, z czego początkowo przez półtora roku pracował przy dekoracji pałacu biskupów wileńskich w Werkach pod Wilnem, a przez pozostały czas (od 1786 do 1790 r.), związany był z robotami prowadzonymi w wileńskiej katedrze. Za wszystkie prace otrzymał łącznie 62700 złotych polskich (14 850 za prace w Werkach i $47850 \mathrm{w}$ katedrze), przy pensji rocznej 550 czerwonych zł (czyli 9900 złotych polskich), z tego 400 za prace wykonywane „wedle kontraktu”, a 150 za „wszelkie wygody”. Ponadto kontraktem zabezpieczona została suma 1800 złotych polskich na podróż artysty z Rzymu do Wilna i z powrotem ${ }^{26}$, co świadczy o tym, że traktował on swój wyjazd z ojczyzny jako czasowy.

Wileński okres działalności Righiego rozpoczęła praca w Werkach, gdzie w przebudowywanym przez Wawrzyńca Gucewicza na zlecenie biskupa Massalskiego pałacu wyko-

\footnotetext{
${ }^{25}$ Accademia Nazionale di San Luca w Rzymie, Archivio Storico, vol. 54: Principiano a scrivessi in q[ues] to libbro li decreti delle Congregazioni Accademiche dall' di 7 Gennaro 1781 fino al 7 aprile 1793, k. 60.

${ }^{26}$ Vladas DREMA, „Nieznane materiały do działalności Wawrzyńca Gucewicza, Piotra Rossi, Tomasza Righi oraz Karola i Kazimierza Jelskich”, Biuletyn Historii Sztuki, 28: 1966, nr 3-4, s. 368 i aneks 2.
} 


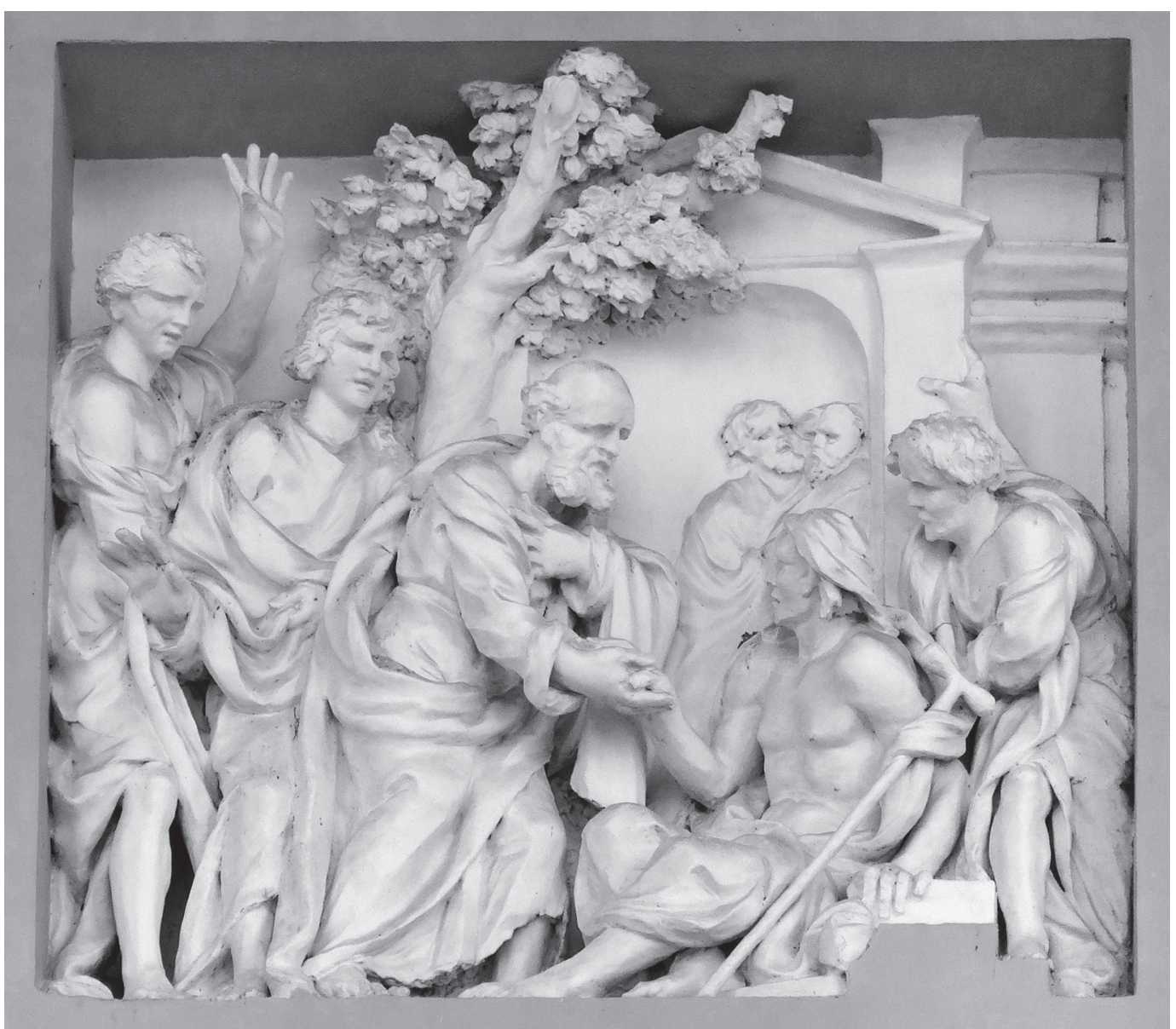

12. Tommaso Righi, Uzdrowienie chromego, stiuk w technice narzutu, między 1786 a 1790. Wilno, katedra św. Stanisława.

Fot. Katarzyna Mikocka-Rachubowa

nał nieokreślone bliżej prace rzeźbiarskie, zapewne reliefy z wielopostaciowymi scenami zdobiące fasadę budowli ${ }^{27}$. W tympanonie trójkątnego frontonu środkowego portyku umieszczono tam relief z przedstawieniem Cyncynata orzącego wołami pole, a w prostokątnych polach wieńczących ryzality boczne reliefowe sceny z wyobrażeniem prac rolnych. Wygląd zewnętrzny pałacu znany jest z rycin pochodzących z około 1830 r., m.in. z litografii wykonanej według rysunku Józefa Oziębłowskiego (w zbiorach Muzeum Narodowego w Warszawie) ${ }^{28}$ i z dwóch akwareli Marcelego Januszewicza (w zbiorach muzealnych pałacu w Werkach).

Głównym polem artystycznej aktywności Righiego była jednak prowadzona wówczas pod kierunkiem Gucewicza przebudowa katedry w Wilnie, gdzie artysta pracował przez prawie pięć lat. Jego dziełem jest tam duży zespół rzeźb zdobiących fasadę budowli, złożony z sześciu posagów i sześciu wielopostaciowych reliefów, a także dwa posagi alegoryczne we wnętrzu. Na fasadzie świątyni stoją po obu stronach portyku, w zwieńczonych trójkątnymi frontonami niszach, posagi: Abrahama (il. 5) z lewej i Mojżesza (il. 6) z prawej strony (u stóp Mojżesza artysta umieścił sygnaturę), a między pilastrami portyku,

\footnotetext{
${ }^{27}$ LORENTZ, „Wawrzyniec Gucewicz ...”, s. 376; też: CIAMPI, Notizie ..., s. 120; SOBIESZCZAŃSKI, op. cit., s. 269; DAUGNON, op. cit., s. 284.

${ }^{28}$ Repr. w: LORENTZ, „Wawrzyniec Gucewicz ...”, il. 11 na s. 373.
} 


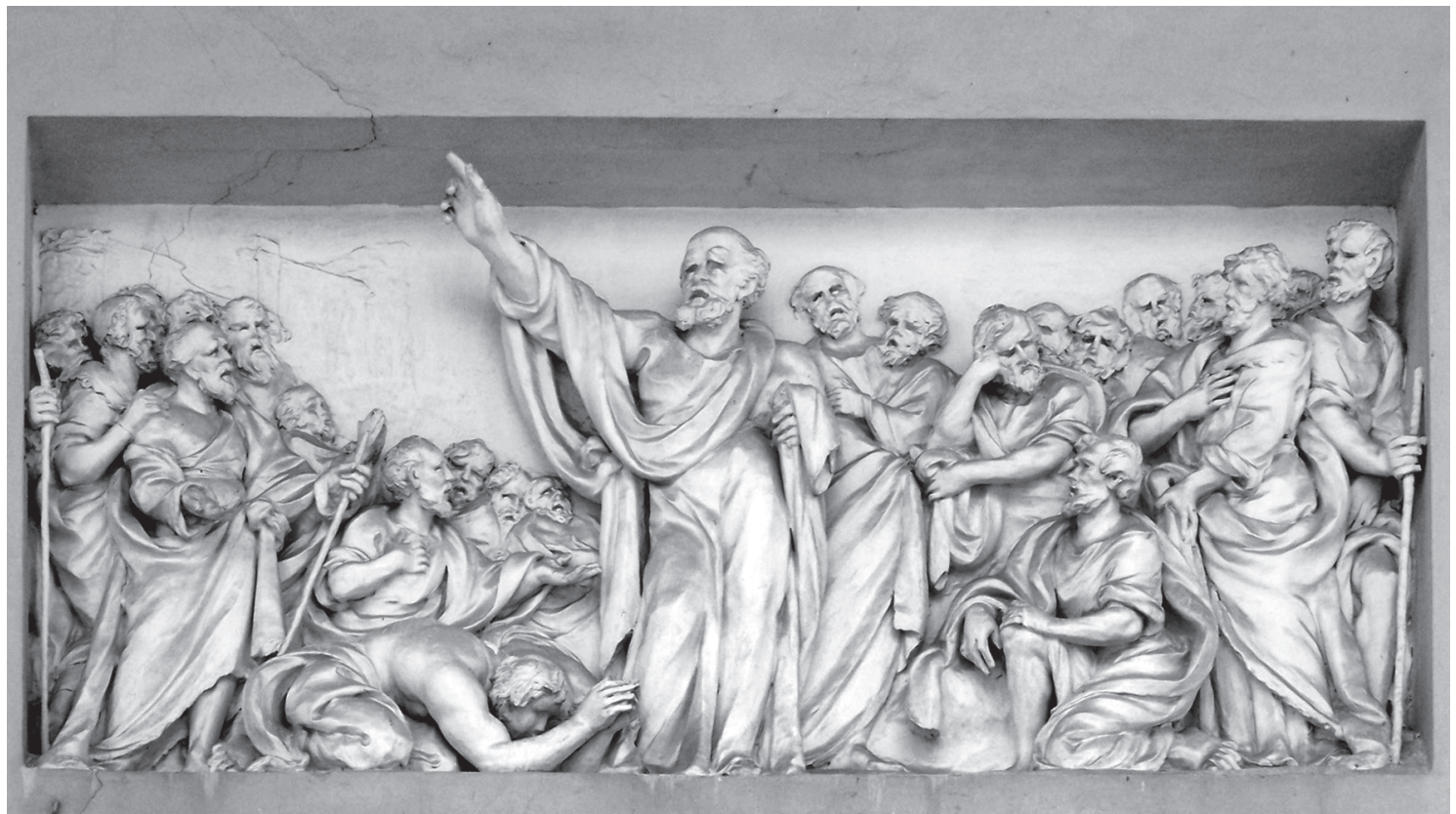

13. Tommaso Righi, Kazanie św. Piotra, stiuk w technice narzutu, między 1786 a 1790. Wilno, katedra św. Stanisława. Fot. Katarzyna Mikocka-Rachubowa

w półkoliście zamkniętych niszach, figury czterech ewangelistów: św. Mateusza (il. 7) i św. Marka (il. 8) z lewej oraz św. Łukasza (il. 9) i św. Jana Ewangelisty (il. 10) z prawej strony. Nad figurami ewangelistów i nad wejściem do świątyni umieszczono pięć prostokątnych reliefów ze scenami z Dziejów Apostolskich, które przedstawiają: Zesłanie Ducha Świętego (il. 11), Uzdrowienie chromego (il. 12), Kazanie św. Piotra (il. 13; to największy relief usytuowany centralnie nad wejściem), Św. Pawła uzdrawiajacego chorego (il. 14) oraz Śmierć Ananiasza i Safiry (il. 15). Dziełem Righiego jest również widniejący w tympanonie portyku relief z przedstawieniem Ofiary Noego (il. 16). Rzeźby te są widoczne na rycinie z 1824 r. przedstawiającej elewację kościoła katedralnego w Wilnie $^{29}$ (il. 17) i na litografii z 1847 r. z widokiem frontalnym katedry ${ }^{30}$ (il. 18). Dwa inne posagi, stojące we wnętrzu katedry, usytuowane w niszach ścian zamykających nawy boczne od strony prezbiterium, wyobrażają Miłość Boga (przy zakrystii; il. 19) i Miłość bliźniego (przy kaplicy św. Kazimierza; il. 20). Wszystkie te rzeźby wykonane zostały w stiuku w technice narzutu, a powstały między 1786 a 1790 r. (wiadomo, że w początkach czerwca 1786 r. Righi pracował nad posagiem Mojżesza) ${ }^{31}$.

\footnotetext{
${ }^{29}$ Leonard SCHMIDTNER, Zbiór celniejszych gmachów Miasta Stolecznego Warszawy..., zeszyt III, Warszawa 1824, tabl. 1.

${ }^{30}$ Fasada katedry w Wilnie z rzeźbami Tommasa Righiego, litografia z 1847 r. (litografował Isidore-Laurent Deroy, rysował Wasilij Semenowicz Sadownikow), [w:] Jan Kazimierz WILCZYŃSKI, Album wileńskie, Seria I, zeszyt 1, Wilno 1850; por. też Jadwiga JAWORSKA, ,Album Wileńskie w zbiorach graficznych Muzeum Narodowego w Warszawie", Rocznik Muzeum Narodowego w Warszawie, 20: 1976, s. 235, poz. 9 i il. 7 na s. 236.

${ }^{31}$ Ludwika BYSZEWSKA, Żurnal podróży do Wilna z roku 1786, oprac. Piotr JAMSKI, wstęp Ewa MANIKOWSKA, Wilno 2008, s. 143: podobno i Pan Rygi poszedt do kościoła katedralnego swego Mojzesza robić, którego nie widziatam; powiadano, że to dopiero ebosz [ébouche, szkic - K. M.-R.]. Byszewska (op. cit., s. 146) pisze, że zwiedzała atelier rzeźbiarza Righiego, gdzie oglądała wiele dzieł sztuki przywiezionych z Rzymu dla biskupa Massalskiego, a Sobieszczański (op. cit., s. 269) przytacza anegdotę o modelowaniu przez Righiego posagu Mojżesza z natury; jako model miał artyście posłużyć pewien szlachcic litewski. O rzeźbach katedry w Wilnie ostatnio: MIKOCKA-RACHUBOWA, Rzeźba włoska w Polsce ..., t. 2, s. 491-499.
} 


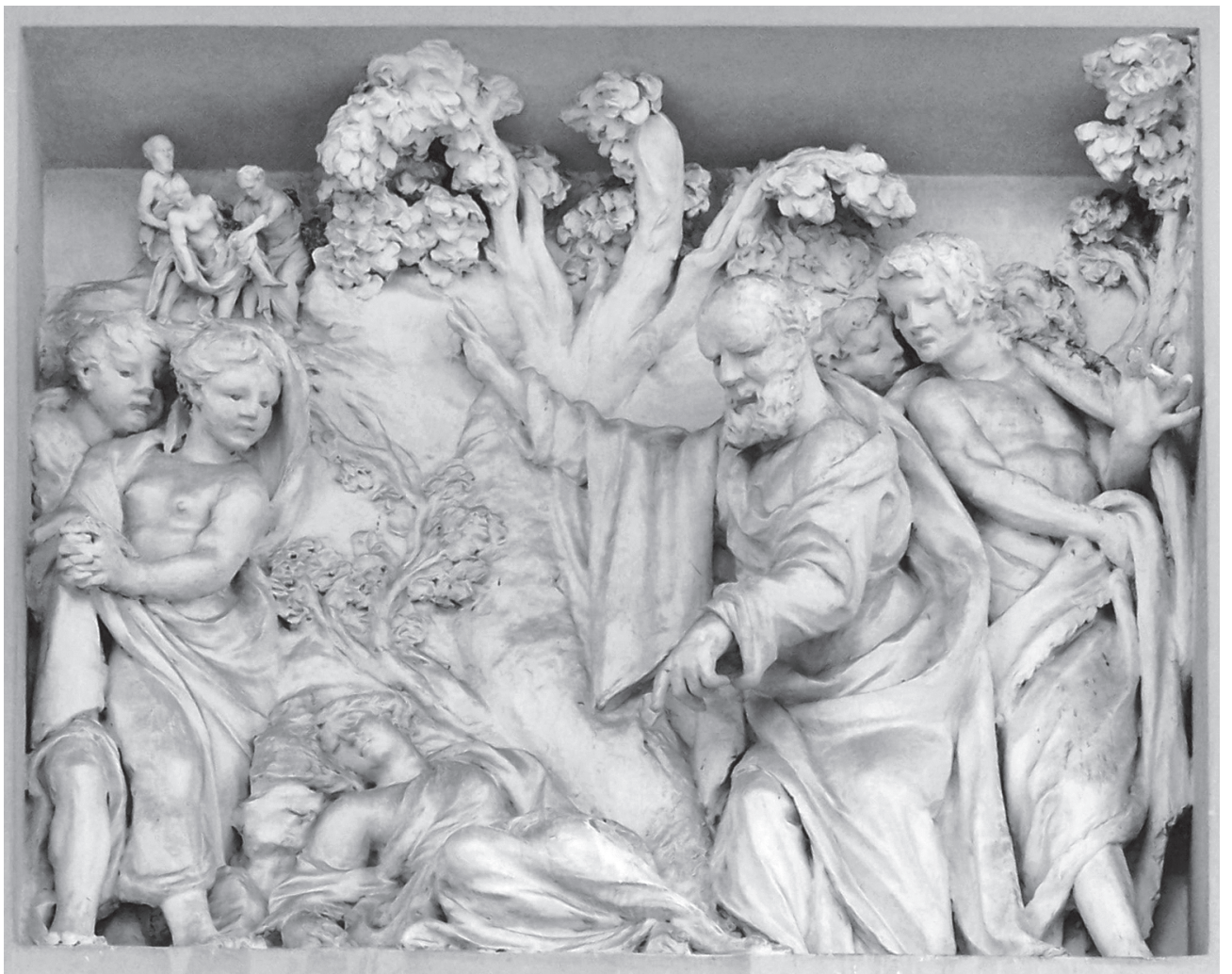

14. Tommaso Righi, Św. Paweł uzdrawiający chorego, stiuk w technice narzutu, między 1786 a 1790. Wilno, katedra św. Stanisława. Fot. Katarzyna Mikocka-Rachubowa

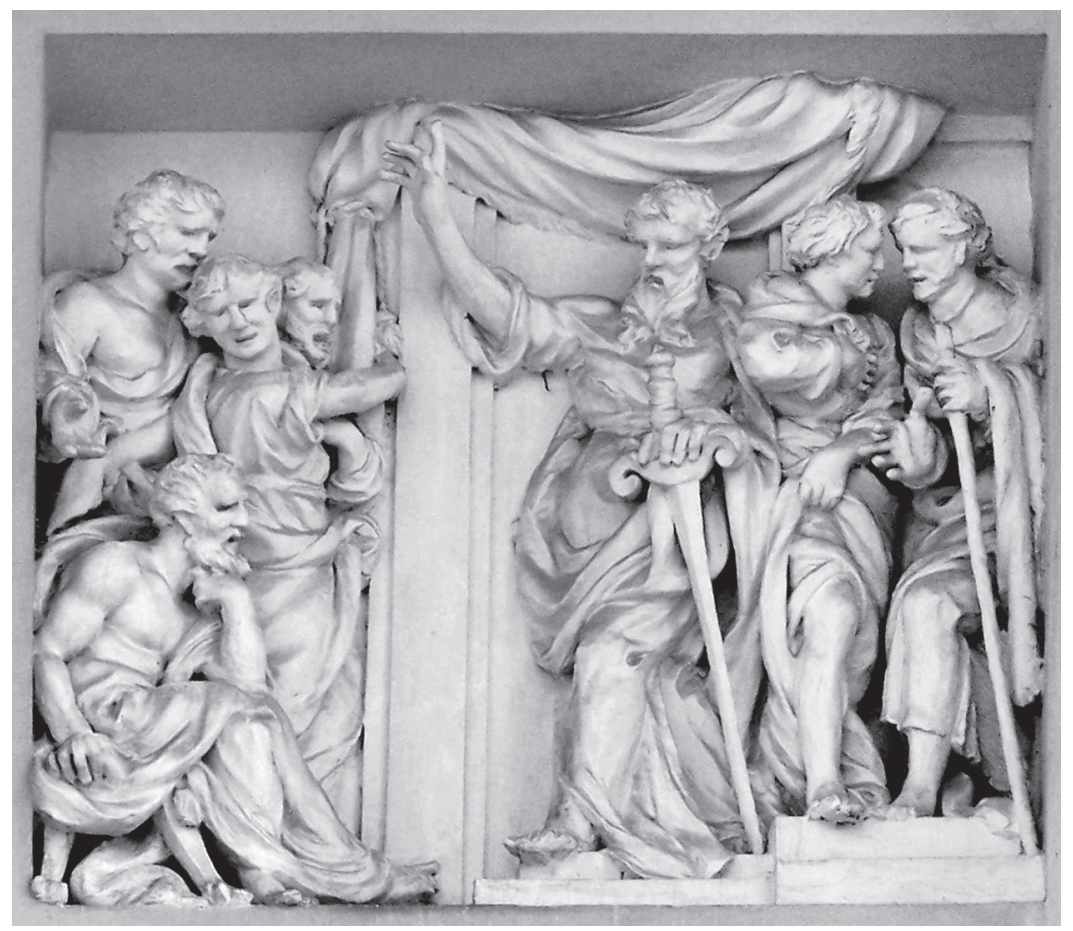

15. Tommaso Righi, Śmierć Ananiasza i Safiry, stiuk $w$ technice narzutu, między 1786 a 1790. Wilno, katedra św. Stanisława. Fot. Katarzyna Mikocka-Rachubowa 


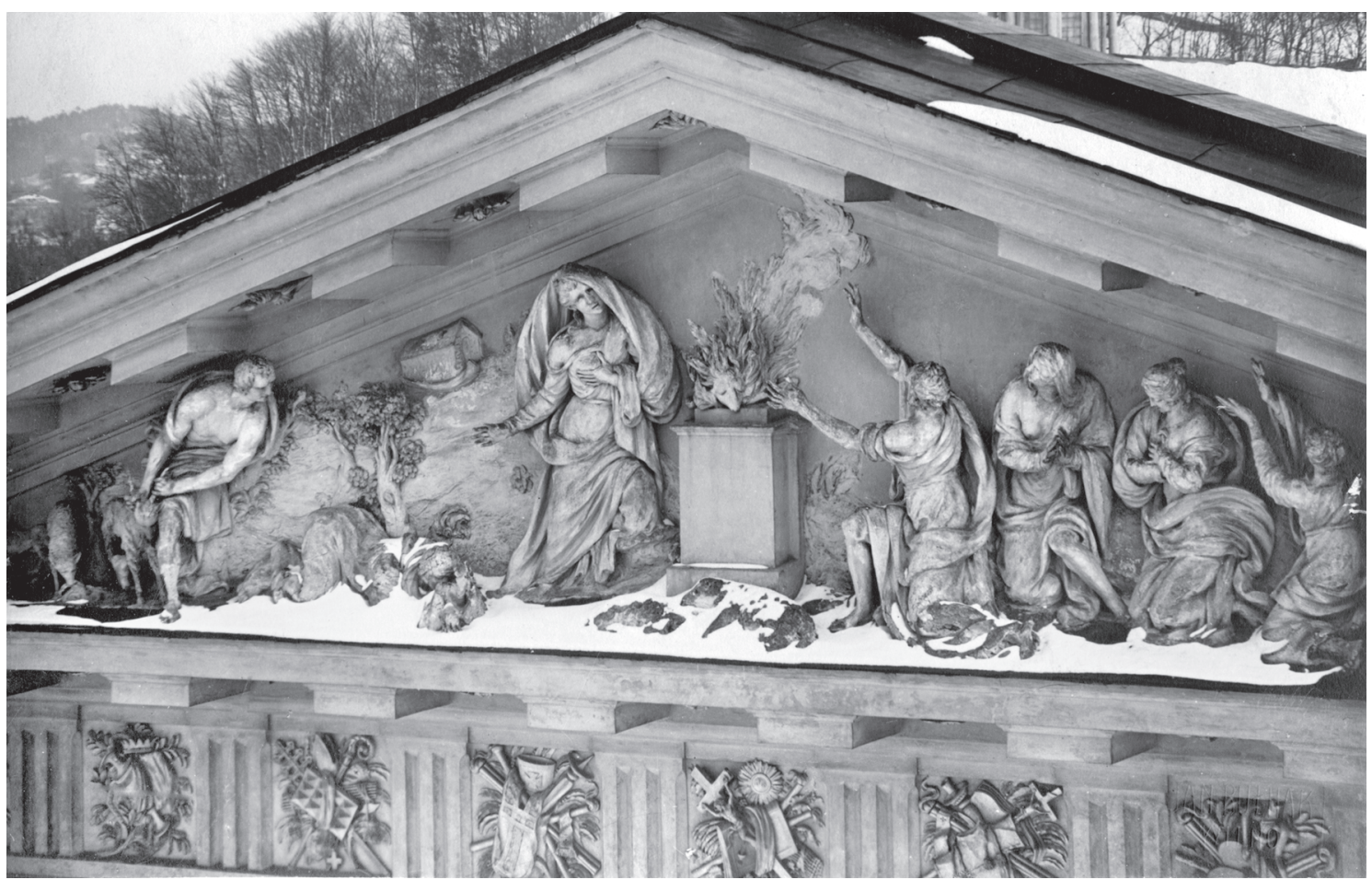

16. Tommaso Righi, Ofiara Noego, stiuk w technice narzutu, między 1786 a 1790. Wilno, katedra św. Stanistawa. Fot. Jan Buthak, przed 1916 r., ze zbiorów Instytutu Sztuki PAN w Warszawie

Rzeźbiarska dekoracja katedry w Wilnie stworzona przez Righiego była przedsięwzięciem, którego zakres przewyższał wszystkie inne prace, jakie artysta wykonał w okresie ponad trzech dekad swojej aktywności w Rzymie. Zamówienia realizowane przez niego w Wiecznym Mieście obejmowały bowiem głównie stiukowe dekoracje wnętrz budowli kościelnych i pałaców, na które składały się medaliony i płyciny z pojedynczymi przedstawieniami i wielopostaciowymi scenami, a także figury aniołów i puttów, główki cherubinów i trofea zdobiące sklepienia, ściany, ołtarze, glorietty oraz obramienia tond i kartuszy. Bogata dekoracja figuralna Salone d'Oro w Palazzo Chigi to liczne opracowane w stiuku reliefowe przedstawienia figuralne rozmieszczone na sklepieniu, pilastrach i w supraportach oraz dekoracje o motywach roślinno-figuralnych w płycinach ścian. We wnętrzach casina Villa Borghese dziełem Righiego jest kilkanaście wielopostaciowych reliefów w stiuku o tematyce mitologicznej. Jego rzymski dorobek obejmuje też pomniki nagrobne z przedstawieniami zmarłych oraz figurami alegorycznymi, aniołami i puttami. Nie znajdujemy w nim natomiast tak monumentalnej realizacji, jaką był wykonany w stiuku zespół rzeźb do wileńskiej katedry, złożony z ośmiu posagów ponadnaturalnej wielkości, pięciu prostokątnych reliefów $\mathrm{z}$ wielopostaciowymi scenami oraz wielkiego figuralnego reliefu zdobiącego tympanon frontonu.

$\mathrm{Z}$ dużym prawdopodobieństwem można przypuścić, że owe posagi i reliefy Tommaso Righi nie tylko wykonywał, ale także, przynajmniej w znacznej części, sam projektował. Wydaje się o tym świadczyć fakt umieszczenia przez niego sygnatury na jednym z posągów zdobiących fasadę. Za tym, że Righi był nie tylko realizatorem, ale także projektantem owych rzeźb przemawiają jeszcze inne argumenty. Wielopostaciowa scena z wyobrażeniem Ofiary Noego znajdująca się w tympanonie świątyni odbiega w pewnych detalach od pierwotnego szkicu przedstawionego przez Gucewicza na widoku katedry 


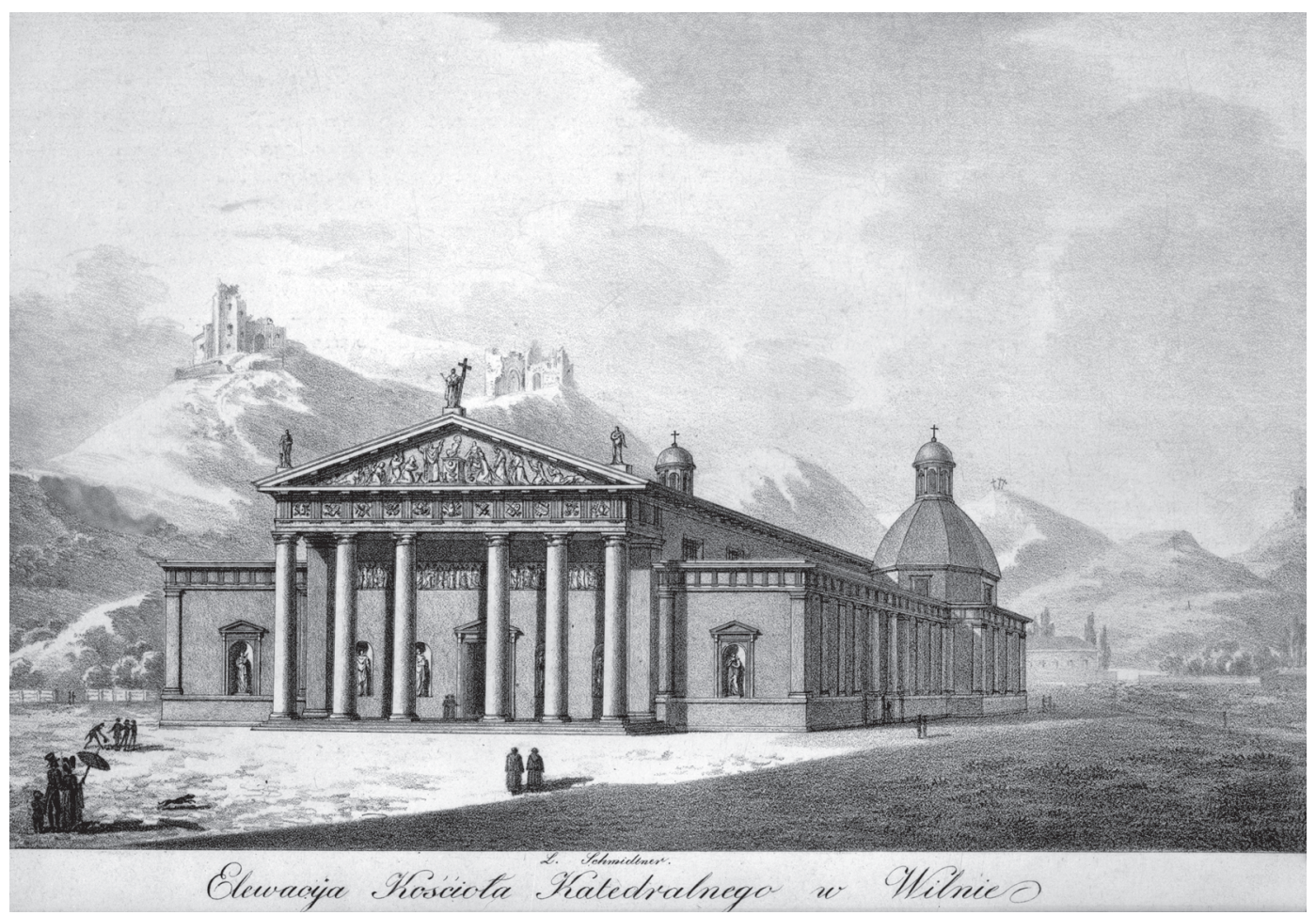

17. Elewacja katedry Św. Stanisława w Wilnie. Repr. wg Leonard Schmidtner, Zbiór celniejszych gmachów miasta stołecznego Warszawy, Warszawa 1824

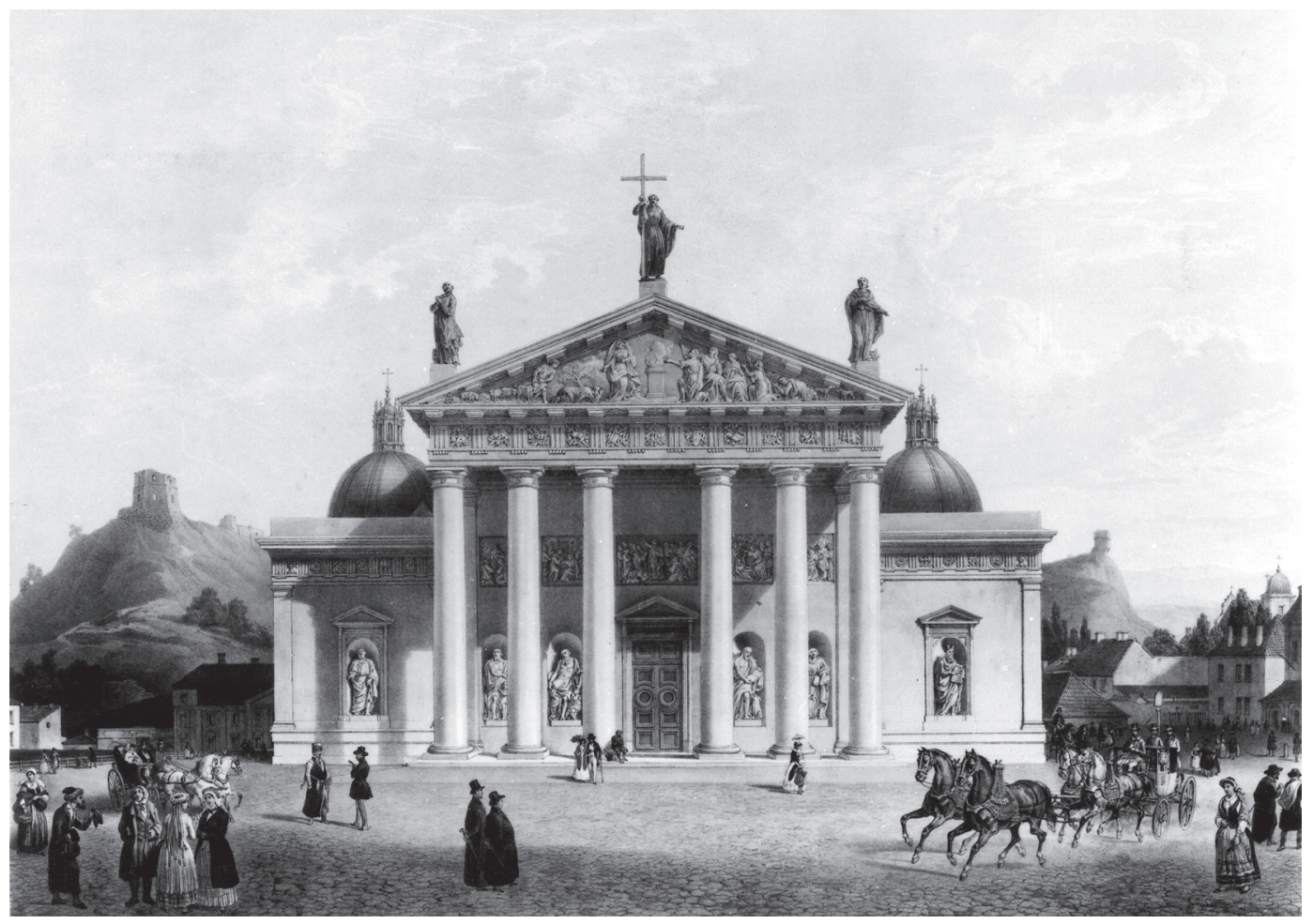

18. Isidore-Laurent Deroy wg rysunku Wasilija S. Sadownikowa, Fasada katedry w Wilnie z rzeźbami Tommasa Righiego, 1847. Litografia w: Album wileńskie Jana Kazimierza Wilczyńskiego, Seria I, zeszyt 1, Wilno 1850 


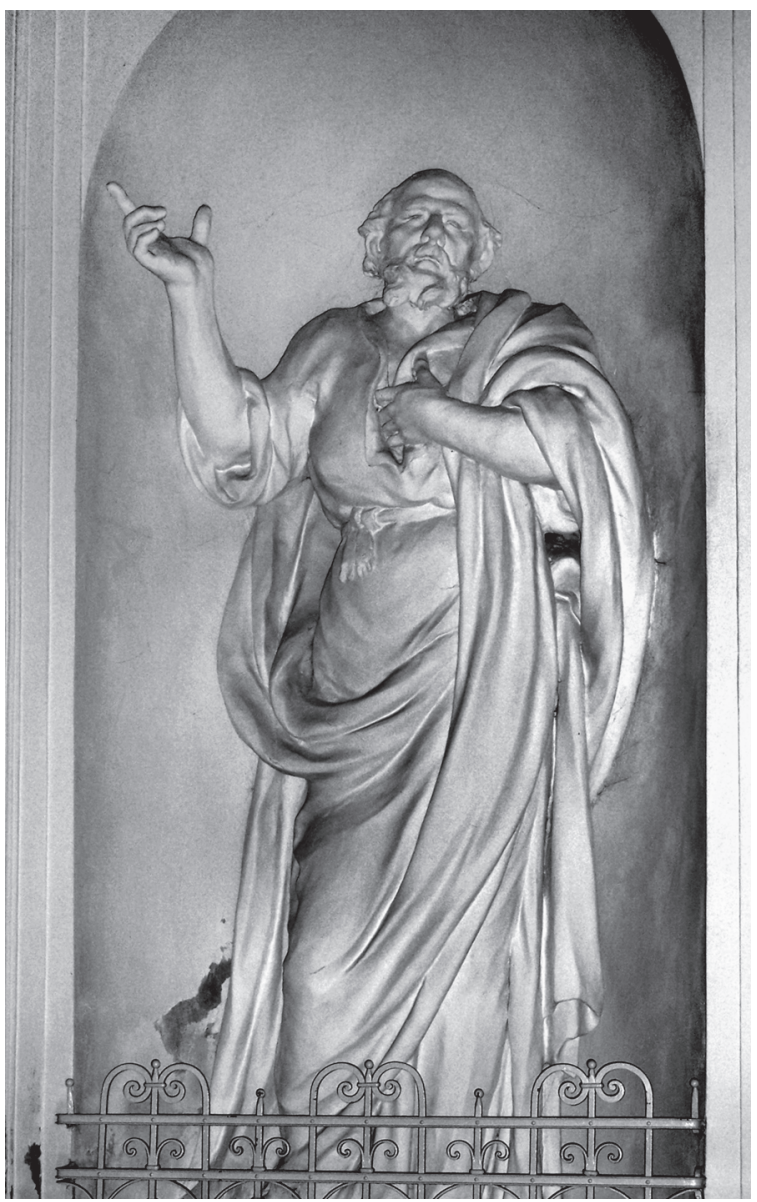

19. Tommaso Righi, Miłość Boga, stiuk w technice narzutu, między 1786 a 1790. Wilno, katedra św. Stanistawa.

Fot. Katarzyna Mikocka-Rachubowa

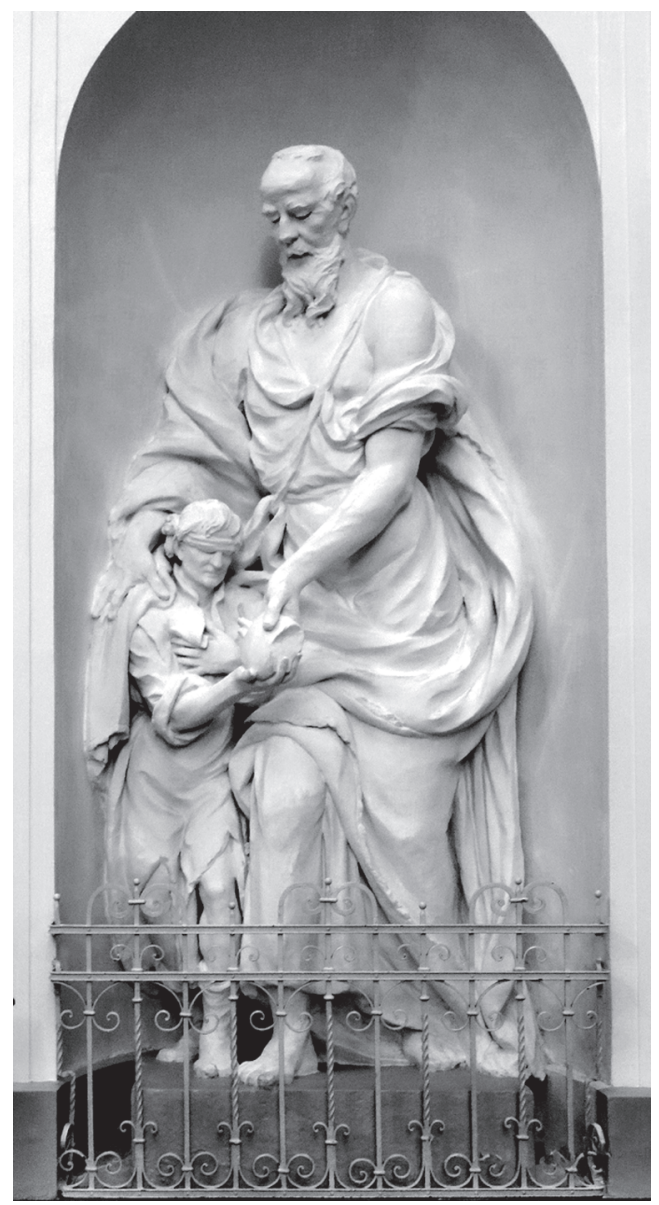

20. Tommaso Righi, Miłość bliźniego, stiuk $w$ technice narzutu, między 1786 a 1790. Wilno, katedra św. Stanisława. Fot. Katarzyna Mikocka-Rachubowa

z 1786 r. Righi zmodyfikował nieco jego plastyczny pomysł, zmieniając układ sceny w myśl założeń kompozycyjnych późnego baroku, co świadczyłoby o tym, że przy realizacji projektu w stiuku artyście pozostawiono pewną swobodę ${ }^{32}$. Inną przesłanką przemawiającą za tym, że Righi sam projektował owe wileńskie rzeźby jest fakt, że w zbiorze biskupa Massalskiego w pałacu biskupim w Wilnie znajdowało się w 1795 r. osiem, wykonanych najpewniej w terakocie, ,modeluszów katedralnych robionych ręką snycerza sławnego Righiego". Były to niewattpliwie modele posagów do katedry: sześć figur mających stanąc na fasadzie i dwie przeznaczone do wnętrza ${ }^{33}$. W zbiorze tym odnotowano wówczas także cztery biusty „,z gliny” (terakoty) robione „,ręką snycerza sławnego Righiego" ${ }^{34}$. Być

\footnotetext{
${ }^{32}$ Na szkicu Gucewicza w scenie Ofiary Noego ołtarz ofiarny jest przesunięty z osi tympanonu ku północy, a figury zorientowane są w jego kierunku; nie wykonano też projektowanego tam rzędu figur pod portykiem, a w metopach w miejsce rozet wstawiono dekoracyjne motywy przedstawiające kościelne utensylia. Por. ŚLEDZIEWSKI, op. cit., s. $4-5$.

${ }^{33}$ DREMA, op. cit., s. 369; autor powołuje się na dokument archiwalny w Centralnej Naukowej Bibliotece Akademii Nauk Litewskiej SRR w Wilnie (obecnie Biblioteka im. Wróblewskich Litewskiej Akademii Nauk w Wilnie), fond 43, akta 7081: Regestr sprzętów [...] Ignacego Massalskiego, k. 11, 15, podaje również, że dwie rzeźby stojące obecnie we wnętrzu katedry były przeznaczone do ołtarza głównego.

${ }^{34}$ Ibid.
} 


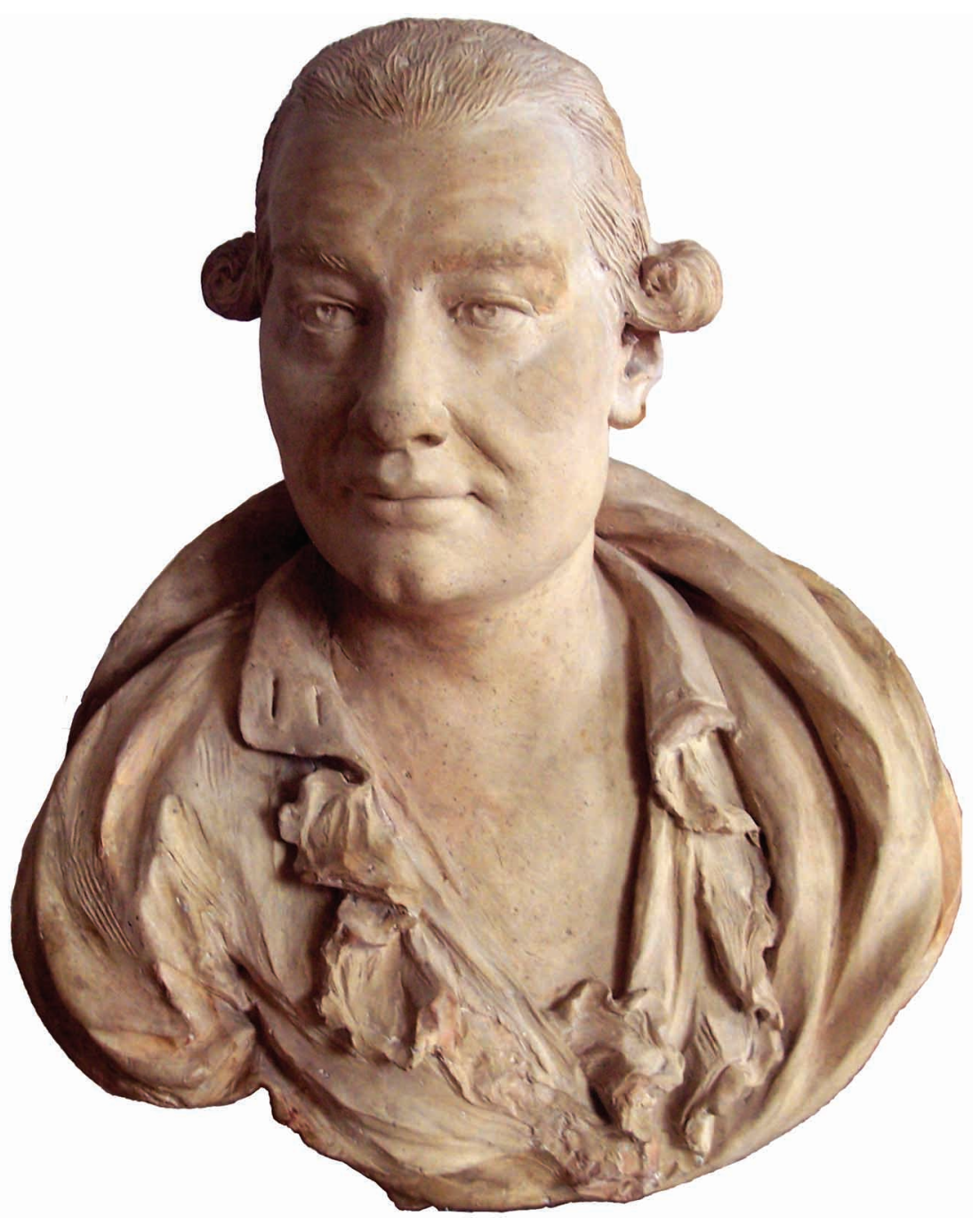

21. Tommaso Righi, Jakub Briotet, terakota, 1789. Wilno, Litewskie Muzeum Sztuki, Oddział Wileńska Galeria Obrazów. Fot. Katarzyna Mikocka-Rachubowa

może któryś z nich był identyczny z popiersiem w terakocie Jakuba Brioteta, profesora chirurgii na uniwersytecie w Wilnie, sygnowanym „RIGHI/ FECIT/ AN\%/ 1789”35 (il. 21). Righi zatem, oprócz prac w Werkach i rzeźb w katedrze, zrealizował w okresie swojej działalności w Wilnie inne jeszcze dzieła.

Rzeźby wykonane przez Righiego do katedry w Wilnie odbiegają zasadniczo swoim artystycznym wyrazem od form klasycystycznej fasady wileńskiej katedry, którą zdobią. Pełne dynamiki, malowniczości i patosu odznaczają się barokową ekspresją, a ich charakter utrzymany jest w konwencjach, w jakich artysta tworzył przez całe swoje życie. Stanowią one rezultat jego rzymskich doświadczeń, a realizując je Righi nawiązał do dzieł znanych mu z rodzinnego miasta. Kompozycja wileńskich figur, ich pozy i gesty, a także

\footnotetext{
${ }^{35}$ Rzeźba o wymiarach $53 \times 48 \times 28$ cm, obecnie w zbiorach Litewskiego Muzeum Sztuki, Oddział Wileńska Galeria Obrazów (nr inw. S. 36), w muzeum od 1940 r., ofiarowana przed 1832 r. do Gabinetu Skulptury Uniwersytetu Wileńskiego przez rektora Szymona Malewskiego. O rzeźbie: DREMA, op. cit., s. 369; MIKOCKA-RACHUBOWA, Rzeźba włoska ..., t. 2, s. 499, tam bibliografia.
} 


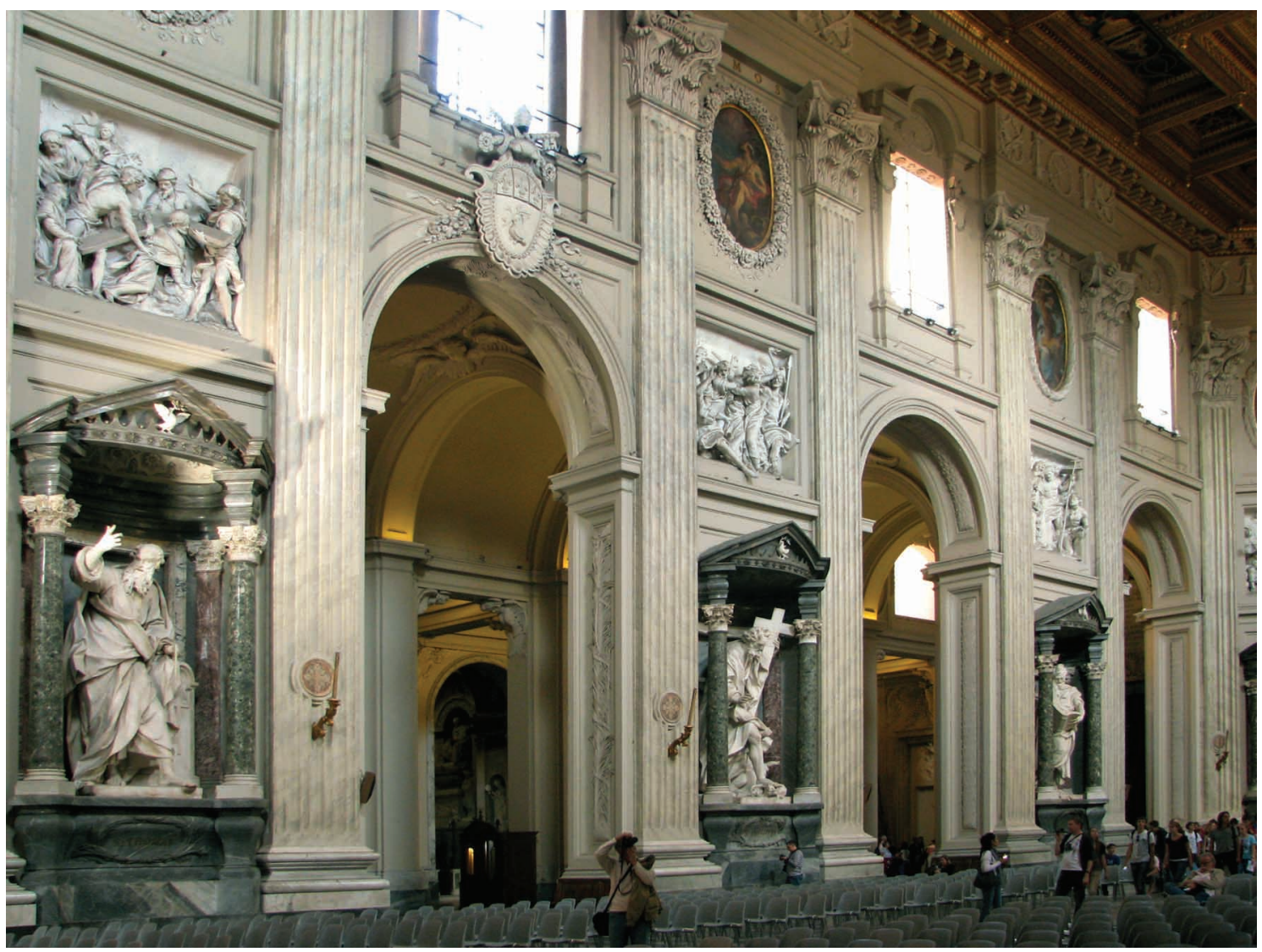

22. Bazylika San Giovanni in Laterano w Rzymie, nawa główna.

Fot. Katarzyna Mikocka-Rachubowa

układ i sposób kształtowania draperii ich szat są bowiem, jak się wydaje, reminiscencją powstałych przed niemal wiekiem marmurowych posagów dwunastu apostołów stojących w niszach nawy głównej bazyliki San Giovanni in Laterano w Rzymie (il. 22). Zespół ten, stanowiący reprezentatywny przykład tendencji panujących w rzymskiej rzeźbie przełomu XVII i XVIII w., został wykonany w latach 1703-1718 przez siedmiu artystów (m.in. Camilla Rusconiego, Pierre'a Legrosa, Pierre-Etienne'a Monnota, Francesca Morattiego) według rysunków Carla Maratty ${ }^{36}$ (il. 23, 25). Podobieństwa między posagami w Rzymie i w Wilnie (il. 23-26) dotyczą nie tylko strony formalnej i stylistycznej samych figur - ich pozy, sposobu oddania ruchu, kształtowania postaci i układu draperii ich szat, ale wyrażają się także w usytuowaniu w Wilnie posagów proroków w niszach zwieńczonych trójkątnymi frontonami, tak jak ma to miejsce w nawie głównej rzymskiej bazyliki, oraz w umieszczeniu nad wszystkimi posagami prostokątnych płycin z wielopostaciowymi reliefowymi scenami. Righi tworząc rzeźby do wileńskiej katedry mógł zatem czerpać inspiracje z monumentalnego zespołu posągów zdobiących główną nawę rzymskiej świątyni, w której pracował w latach 60 . XVIII w. i gdzie jego dziełem są stojące w kapli-

\footnotetext{
${ }^{36}$ Frederic van den BROEDER, ,The Lateran Apostles. The Major Sculpture Commission in Eighteenth-Century Rom”, Apollo, 85: 1967, s. 360-365; Robert ENGGASS, Early Eighteenth-Century Sculpture in Rome: an illustrated catalogue raisonné, The Pennsylvania State University Press, University Park and London 1976, t. 1: Text, s. 39-42, 70-71, 85-87, 99-102, 117, 142-144, 166, t. 2: Plates, il. 30-32, 35-39, 57-66, 85-86, 135-142, 163-167; Angela NEGRO, „La decorazione clementina di San Giovanni in Laterano", [w:] Papa Albani e le arti a Urbino e a Roma 1700-1721, a cura di Giuseppe CUCCO, Venezia 2001, s. 99-109.
} 


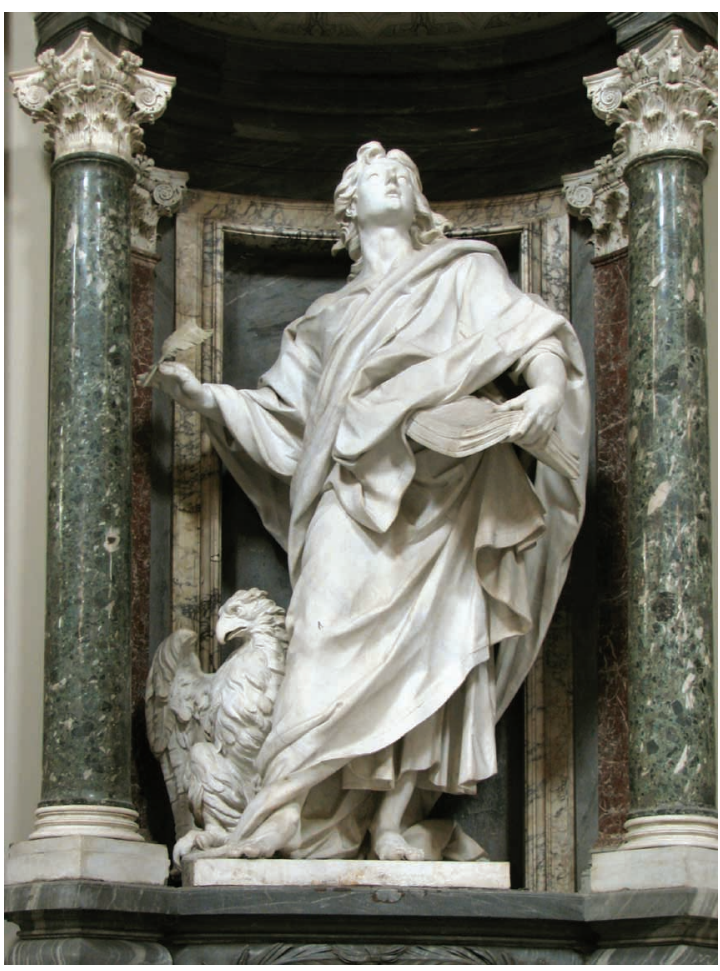

23. Camillo Rusconi, Św. Jan, marmur biały, 1705-1711. Rzym, bazylika San Giovanni in Laterano.

Fot. Katarzyna Mikocka-Rachubowa

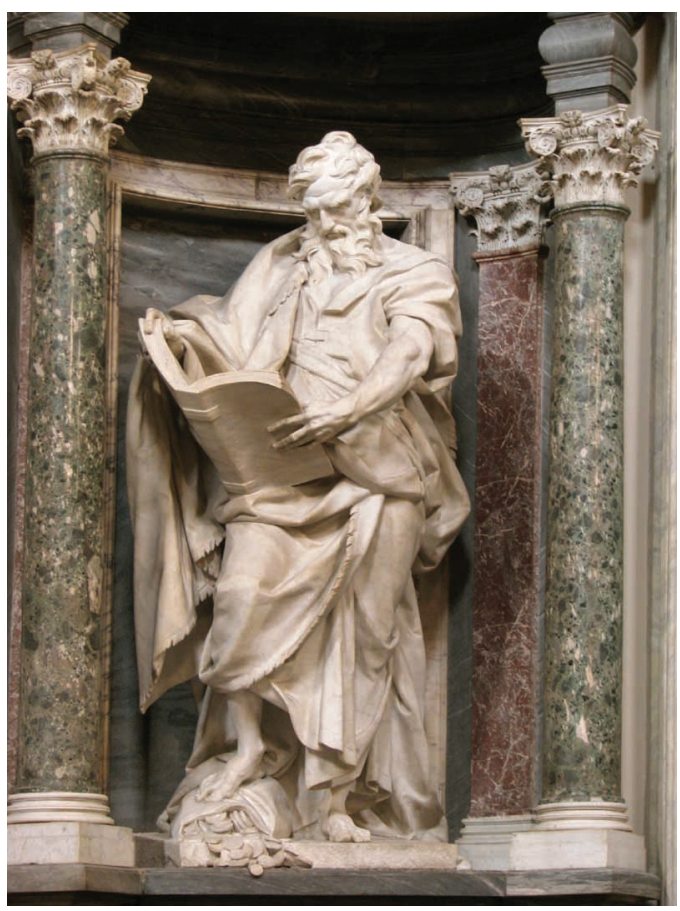

25. Camillo Rusconi, Św. Mateusz, marmur biały, 1711-1715. Rzym, bazylika San Giovanni in Laterano.

Fot. Katarzyna Mikocka-Rachubowa

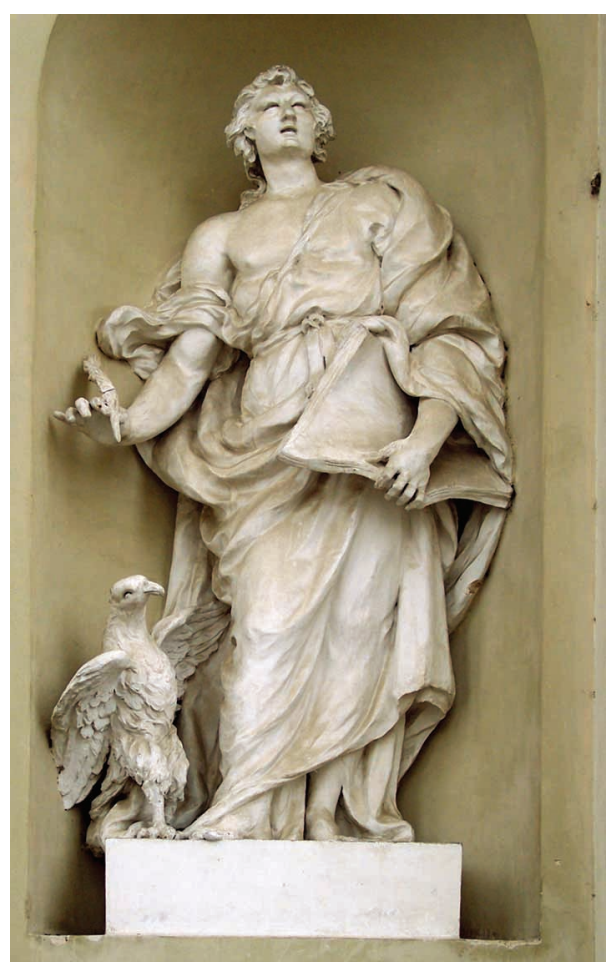

24. Tommaso Righi, Św. Jan, stiuk, między 1786 a 1790.

Wilno, katedra św. Stanistawa. Fot. Katarzyna Mikocka-Rachubowa

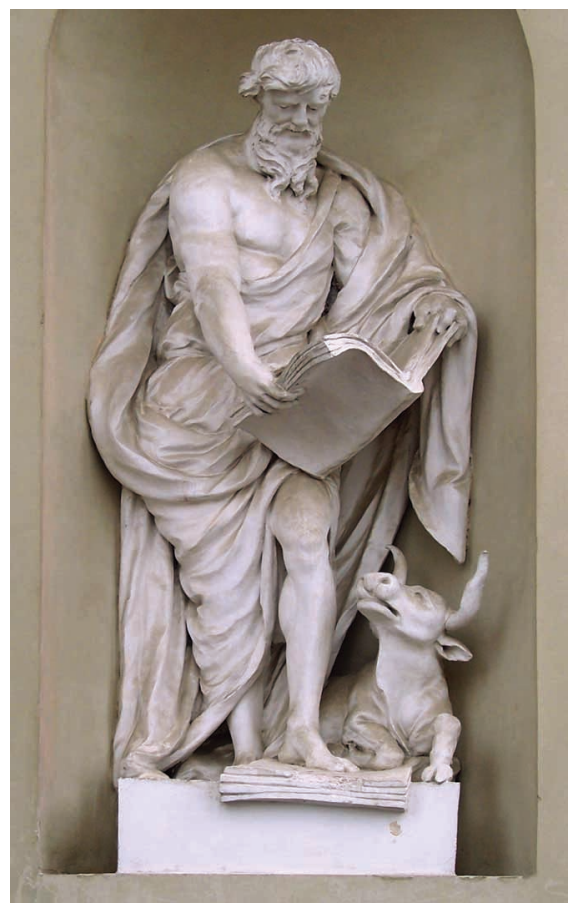

26. Tommaso Righi, Św. Łukasz, stiuk, między 1786 a 1790. Wilno, katedra św. Stanistawa. Fot. Katarzyna Mikocka-Rachubowa 
cy przy Baptysterium wspomniane wyżej pomniki arcybiskupa Niccolò Lercariego, kardynała Niccolò Marii Lercariego i arcybiskupa Alessandra Borgii.

W ostatnim okresie pobytu artysty w Wilnie jego stosunki z biskupem Massalskim nie układały się najlepiej. W liście z marca 1791 r. z Wenecji biskup skarżył się na rzeźbiarza, że ten „darmo pieniądze bierze w zimie nie pracując”. Latem 1791 r. poczyniono ustalenia dotyczące zatrudnienia go na dworze króla Stanisława Augusta w Warszawie ${ }^{37}$. Wkrótce, zapewne jesienią tegoż roku, Righi opuścił Wilno i wyjechał do Warszawy, gdzie w latach 1792-1793 pracował przy rzeźbiarskiej dekoracji letniej rezydencji króla w Łazienkach. Obok drobnych prac dekoracyjnych w łazienkowskim pałacu, artysta wykonał wówczas zespół rzeźb zdobiących attykę Amfiteatru (teatru Na Wyspie) w Łazienkach: dwie figury personifikujące Tragedię i Komedię oraz szesnaście posągów siedzących dramaturgów, według projektów André Le Bruna, ,pierwszego rzeźbiarza” króla Stanisława Augusta. Rzeźby te, wykonane w stiuku, nie zachowały się do naszych czasów, ale w łazienkowskim parku stoją dwa odkute przez Righiego w piaskowcu posagi personifikujące rzeki Wisłę i Bug. Przez kilka następnych lat artysta, pozostający w trudnej sytuacji finansowej, starał się o wypłatę zaległych wynagrodzeń, podpisując pokwitowania „Tommaso Righi Scultore Accademico" lub „Tommaso Righi Scultore Accademico di Roma”,38. Pomimo ostatecznego uregulowania kwestii finansowych w czerwcu 1797 r. Righi nie wrócił do Włoch, ze względu zapewne zarówno na stan zdrowia, jak i brak wystarczających środków finansowych. Zmarł w Warszawie w końcu 1802 r. $^{39}$

Dorobek artystyczny Tommasa Righiego stanowią w przeważającej większości dzieła powstałe w Rzymie. Pochodzące ze schyłkowego okresu jego twórczości posagi i reliefy zdobiące katedrę w Wilnie, które w dużej części zapewne sam projektował, tworzą zespół wyróżniający się na tle całego jego oeuvre ze względu zarówno na liczbę i skalę, jak na walory artystyczne składających się nań dzieł. Charakter tych rzeźb wyraźnie pokazuje, że Righi do ostatnich lat życia pozostał epigonem późnej fazy rzymskiego baroku, a jego polska twórczość w porównaniu ze współczesną mu rzeźbą wiodących ośrodków Italii, głównie Rzymu, miała charakter zdecydowanie demodé, powielając typy, schematy i rozwiązania popularne w Wiecznym Mieście przed półwieczem, znane artyście z czasów jego dawnej rzymskiej świetności.

\footnotetext{
${ }^{37}$ LORENTZ, „Wawrzyniec Gucewicz...”, s. 374; DREMA, op. cit., s. 368-369.

${ }^{38}$ MIKOCKA-RACHUBOWA, „Włoscy rzeźbiarze...”, s. 111-116; ead., Rzeźba włoska ..., t. 2, s. 489-490, 500-506.

39 Ostatnia znana wzmianka o Righim to zapis w diariuszu Vincenza Pacettiego z 8 października 1802 r. o tym, że otrzymał on informację od syna artysty (chodziło o mieszkającego w Rzymie Antonia Righiego), iż ten czuje się dobrze w Warszawie i żyje „w pałacu królewskim”, mając przyznaną dożywotnią rentę (Giornali di Pacetti..., s. 229: Adi 8. [8bre 1802] Con piacere ho havuto nuove dal figlio che Tommaso Righi stà bene in Warsavia, nel palazzo del Rè, e vive con aver fatto un vitalizio con un certo Vkicki (chodziło najpewniej o Onufrego Kickiego, plenipotenta króla do spraw finansowych i kuratora masy spadkowej po śmierci Stanisława Augusta; osobą tą mógł też być Wicki, kapitan gwardii litewskiej, a następnie pułkownik i marszałek dworu króla Stanisława Augusta po jego abdykacji). W Rzymie portret Righiego (il. 2), razem z wizerunkiem jego teścia Antonia Bicchierai, został włączony do zbiorów Akademii Św. Łukasza 2 sierpnia 1802 r. Oba portrety namalował w tymże 1802 r. rzymski malarz Francesco Pulini (1747-1806); por. Giornali di Pacetti ..., s. 223: Adi 10. [Marzo 1802] Due ritratti di Righi e Bicchierai per porli a San Luca si faranno da Pulini, też s. 348: Adi 12. Xbre 1806. È morto Francesco Pulini, pittore, in età di anni 59., di ottimi costumi, amico antico, di numerosa familia. W aktach Akademii informację o śmierci Righiego podano dopiero 2 października $1808 \mathrm{r}$.
} 


\section{Sculptures of the Vilnius Cathedral and Their Author Tommaso Righi}

The Cathedral of St Stanislaus in Vilnius was remodelled at the instigation of the Vilnius Bishop Ignacy Massalski beginning as of the late 1770s. In 1783-90, the works were headed by the architect Wawrzyniec Gucewicz, who had been first sent by Massalski to study in Rome, and then taken on a tour of North European countries, from where Gucewicz went to study architecture in Paris. Resorting to his Paris experience, in 1784, he created the concept of a monumental Neo-Classical building, authoring designs of the Vilnius Cathedral for Stanislaus Augustus (one of them has been preserved in the former royal collections, Fig. 1). In order to execute a large set of sculptures for the Vilnius Cathedral, in 1784, Bishop Massalski employed the known Roman sculptor Tommaso Righi. In the to-date research no attempt has been made to explain why it was Righi who was brought to Vilnius and not any other sculptor; neither has it been accounted for why the sculptures adorning the Vilnius church differ so much in their character from the Neo-Classicist forms of the façade they were made for.

The initiator and committent the Cathedral's remodelling, namely Bishop Ignacy Massalski (17261794), had been affiliated with Rome from the time of his studies in Sapienza; he also visited the city several times on later occasions; furthermore, he remained in touch with the artists there, purchasing their works of art. The Bishop was on very special terms with the sculptor Vincenzo Pacetti (1746-1820), an important figure among the Roman artistic circles of the latter half of the $18^{\text {th }}$ century. From the early 1770 s until the end of his life, Pacetti wrote a diary, recording all the major events related to his own activity, and information on the personages visiting his studio, thus on the works of art purchased there. In the diary, Bishop Massalski is mentioned on a number of occasions as someone who bought numerous sculptures in Rome, using Pacetti as an intermediary. During his stay in Rome, Massalski frequently visited Pacetti's studio, and examined the sculptures gathered there, intending to buy some of them; Pacetti, in his turn, also visited the Bishop on a number of occasions. Vincenzo Pacetti was a disciple of Tommaso Righi, who 'loved him like a son', and parted with him with much sorrow when Pacetti was leaving his studio in 1766. Following this, Pacetti did maintain close relations with his master, also cooperating with him. Therefore, it seems very likely that it was Vincenzo Pacetti who directly impacted the choice of his former master to be employed by Bishop Massalski to work in Vilnius.

Born in Rome in 1722 or 1723, a disciple of the well-known sculptor Filippo Della Valle, Tommaso Righi (Fig. 2) was an important celebrity among the artistic circles of the Eternal City of the second half of the $18^{\text {th }}$ century. Having started his individual activity in the late $1740 \mathrm{~s}$, he executed tomb sculptures for Rome's churches as well as sculpture decoration for churches and palaces in the city; they were most frequently after the designs of other artists, though there are works known as both his design and execution. He was member of the most important Roman artistic associations and academies, such as the Congregazione dei Virtuosi al Pantheon or the Academy of Saint Luke where he performed many functions and served as a professor. For a number of years his career was quite successful, while his activity met with high appreciation; he unquestionably was one of the most interesting and creative representatives of sculpture in the Rome of late Baroque. Therefore, the question arises why the artist enjoying important prestige throughout his life in Rome's environment made up his mind to travel to distant Vilnius, at an already advanced age by the then standards. It can be assumed that what prompted him was the obvious decline of his artistic activity gradually more visible in the late 1770s. Lack of orders, resulting in financial difficulties evidently afflicted the financial standing of himself and his family, while the personal difficulties were additionally increased by the artistic production of Rome at the time. Not particularly interested in his art in the Antique, Righi was unable to apply the opportunities provided by the general at the time praxis of restoring, copying, and imitating Antique works, and the trade in ancient sculptures developing widely, the two yielding significant renown and high profits to Rome's sculptors. Being commissioned fewer works in Rome, the artist may have made attempts to continue his activity at a centre distanced from his home town, where the tendencies in harmony with his late Baroque repertory were still in vogue. He, therefore, took advantage of Bishop Massalski's invitation who employed him as his court sculptor in Vilnius in 1784.

Righi left Rome for Poland on 17 May 1784. On the way to Vilnius he had a stopover in Warsaw, carrying a recommendation letter he had been given 
in Rome to Papal Nuncio in Poland Gaetano Ghigiotti. (It was to the Nuncio that Righi sent letters from Vilnius in 1788 asking for protection for his son Antonio living in Rome). It may have been thanks to his stay in Warsaw on that occasion that in August 1785 King Stanislaus Augustus was invited to join the Academy of St Luke as an honorary member which happened 'agli stimoli del suo individuo Tommaso Righi'.

Righi remained employed in Vilnius for 6 years and 4 months. Initially, for 18 months he worked on the decoration of the Vilnius Bishops' Palace in Werki near Vilnius, where he executed some undefined sculpture works, most likely bas-reliefs with multi-figure scenes adorning the building's façade. Subsequently, in 1786-90, he was contributing to the works at the Vilnius Cathedral. In total, he received 62,700 Polish zlotys $(14,850$ for the works at Werki and 47,850 at the Cathedral); additionally, the contract included the allowance of 1,800 zlotys to cover the travel expenses from Rome to Vilnius and back.

As for the Vilnius Cathedral, it features 6 statues and 6 multi-figure bas-reliefs on the façade, as well as 2 statues inside, all of them stucco. The façade has the following statues flanking the portico in niches crowned with triangular pediments: Abraham (Fig. 5) and Moses (Fig. 6; the artist placed his signature at the feet of Moses), while 4 Evangelists were situated in niches amidst the portico pilasters: St Matthew (Fig. 7) and St Mark (Fig. 8) on the left, with St Luke (Fig. 9) and St John the Evangelist (Fig. 10) on the right. Above the Evangelists' figures and the entrance to the church five rectangular bas-reliefs with the scenes from the Acts of the Apostles are found: The Pentecost (Fig. 11), The Healing of a Lame Man (Fig. 12), St Peter Preaching (Fig. 13), St Paul Healing a Sick Man (Fig. 14), and Death of Ananias and Sapphira (Fig. 15). Another work by Righi is also the bas-relief in the portico tympanum Noah Offers a Sacrifice (Fig 16). Inside the Cathedral, there are statues personifying Love of God (Fig. 19) and Love of Neighbour (Fig. 20). Not only did Righi most likely execute those, but he may have designed them, too. In 1795, Bishop Massalski's collection at the Vilnius Bishops' Palace boasted 8 models of statues for the Cathedral made by Righi, as well as four busts in terracotta (one of them possibly being the bust of Jakub Briotet, signed: 'RIGHI/ FECIT/ ANo / 1789', Fig. 21).

The set of sculptures for the Vilnius Cathedral was a large project whose range exceeded that of Righi's works from an over 30-years' span of his activity in Rome. Dynamic, picturesque, and lofty, the sculptures emanate Baroque expression, unharmonized in their artistic impression with the Neo-Classicist façade of the Vilnius Cathedral. When creating them, the artist made reference to the works he knew from his home town. The composition of the Vilnius figures, their poses and gestures, as well as the arrangement and shaping of the robes' draperies seem to be reminiscent of marble Apostles standing in the niches of the nave of the San Giovanni in Laterano Basilica in Rome (Fig. 22). That cycle was executed in $1703-18$ by seven artists (e.g. Camillo Rusconi, Pierre Legros, Pierre-Etienne Monnot, Francesco Moratti) after the drawings by Carlo Maratta (Figs. 23, 25). The likeness between the statues in Rome and in Vilnius (Figs. 23-26) can be found not only in the formal and stylistic layer of the figures, but also in the placing of the Vilnius prophets' statues in niches crowned with triangular pediments, just like in the Roman basilica, with multi-figure bas-relief scenes featured in rectangular panels above all the statues. When creating the sculptures for the Vilnius Cathedral, Righi could thus draw inspiration from the monumental statues adoring the interior of the Rome San Giovanni in Laterano Basilica, at which he had been employed in the 1760s. In the Sante Seconda e Ruffina Chapel of the Baptistery by the Basilica the statues he executed can be found; they include the monuments of Archbishop Niccolň Lercari (1760), Cardinal Niccolò Maria Lercari (1761), and also of Archbishop Ales-sandro Borgia (1767), the latter signed "THOMAS RIGHI INVENIT ET SCULPSIT” (Fig. 3).

In autumn 1791, Righi left Vilnius for Warsaw where he was employed at the court of Stanislaus Augustus. In 1792-93, he worked on the decoration of the King's summer residence in Łazienki. There, he executed some minor decoration works for the Palace and a set of stucco statues designed by André Le Brun (the 'first sculptor' of King Stanislaus Augustus) in the attic of the amphitheatre: two figures personifying Tragedy and Comedy and 16 figures of seated playwrights (unpreserved). In the Łazienki Park there are two Righi's statues in sandstone personifying the Vistula and Bug Rivers. For the next several years the artist strived to receive his overdue salary signing his documents as 'Tommaso Righi Scultore Accademico' or 'Tommaso Righi Scultore Accademico di Roma'. He did not return to Italy, most likely due to his ill health, but also to the lack of sufficient financial means, dying in Warsaw in late 1802. Until his last days he remained the epigone of the late Roman Baroque, while all his Polish art was but a repetition of the types, schemes, and solutions popular in Rome half a century earlier, and known to him from the times of the former glory. 